\title{
UV transmission in Norwegian marine waters: controlling factors and possible effects on primary production and vertical distribution of phytoplankton
}

\author{
Svein Rune Erga ${ }^{1, *}$, Kjetil Aursland $^{1}$, Øyvind Frette ${ }^{2}$, Børge Hamre ${ }^{2}$, \\ Jon Kåre Lotsberg ${ }^{2}$, Jakob. J. Stamnes ${ }^{2}$, Jan Aure ${ }^{3}$, Francisco Rey ${ }^{3}$, Knut Stamnes ${ }^{4}$ \\ ${ }^{1}$ Department of Biology, University of Bergen, Jahnebakken 5, 5020 Bergen, Norway \\ ${ }^{2}$ Department of Physics and Technology, University of Bergen, Allègt. 55, 5007 Bergen, Norway \\ ${ }^{3}$ Institute of Marine Research, PO Box 1870 Nordnes, 5817 Bergen, Norway \\ ${ }^{4}$ Stevens Institute of Technology, Hoboken, New Jersey 07030, USA
}

\begin{abstract}
We investigated the ultraviolet radiation (UVR) transmission properties of Norwegian oceanic, coastal and fjord waters, and how they influence the primary production and vertical distribution of phytoplankton. Values of the $1 \%$ UVR attenuation depth and diffuse attenuation coefficients $\left(K_{\mathrm{d}}\right)$ in the Greenland and Norwegian Seas (GNS), in the coastal waters of south-western Norway (SWN) and in the Samnanger fjord (SAF) are presented. Maximum penetration of UVR in the GNS was confirmed by $K_{\mathrm{d}}(320)=0.25 \mathrm{~m}^{-1}$, and mimimum penetration in the SAF, by $K_{\mathrm{d}}(320)=9 \mathrm{~m}^{-1}$. In the GNS, $K_{\mathrm{d}}$ and chlorophyll a $(\mathrm{chl}$ a) were closely correlated, while coloured dissolved organic matter (CDOM) was the main contributor to ultraviolet (UV) attenuation in the SAF. Also, in SWN waters, CDOM was more important than chl a for UV attenuation, but less important than in SAF waters. In GNS and SAF waters the average vertical distribution of chl a had its maximum in the upper 10 and $7.5 \mathrm{~m}$ of the water column, respectively, while in SWN waters it had its maximum at 20 $\mathrm{m}$. The depths with the highest photosynthetic rates per unit volume decreased successively from the oceanic waters of the GNS via the coastal waters of the SWN to the fjord waters of the SAF. Under similar PAR intensities, however, the water column photosynthetic efficiency (integrated carbon assimilation/chl a ratio) was highest in SWN waters. Maximum and mean percentage potential for inhibition of the estimated (from PAR and UV) primary production due to UVR at a depth of $5 \mathrm{~m}$ were 11 and $4.3 \%$ in the GNS, 3.2 and $0.9 \%$ in the SWN and 0.5 and $0.1 \%$ in the SAF. The UVR potential for inhibition was significant down to a depth of $10 \mathrm{~m}$ in the GNS, down to a depth of $5 \mathrm{~m}$ in the waters of the SWN, while it was seldom found deeper than $3 \mathrm{~m}$ in the SAF. These variations could be ascribed to differences in CDOM concentrations and mixed-layer depths. The optical properties of the investigated water masses were found to be highly influenced by the circulation patterns.
\end{abstract}

KEY WORDS: UV transmission · Norwegian waters $\cdot$ Phytoplankton $\cdot$ Primary production Resale or republication not permitted without written consent of the publisher

\section{INTRODUCTION}

In spite of relatively short growth seasons the oceanic and coastal waters surrounding Norway are among the most productive in the world (Blindheim \& Skjoldal 1993, Nielsen et al. 1993). Spawning of the commercially most important fish stocks takes place at certain sites along the Norwegian coast, within the fjords and in shallow regions in the oceanic realm. Häder et al. (1995) showed that in the marine ecosys- tem even a small increase or a temporary fluctuation in the UV-B ( 280 to $320 \mathrm{~nm}$ ) radiation may cause permanent damage to sensitive species. According to Helbling \& Villafañe (2002) little has been done to investigate possible consequences of increased levels of UV-B radiation for the marine food web in Norwegian Arctic waters and subarctic waters in general.

Stratospheric ozone and clouds are the main barriers preventing incoming UV-B radiation from reaching the earth's surface (Tsay \& Stamnes 1992). A decline in 
total ozone has been observed at middle and high latitudes in the Northern Hemisphere during the last decades (Stolarski et al. 1992, Jokela et al. 1993, Varotsos et al. 1998, Dahlback 2002). According to Austin et al. (1992), Bjørn et al. (1998) and Hessen (2002), this tendency is expected to continue in the 21st century. In addition, there is a tendency towards more rapid depletion of the ozone layer over Scandinavia than over most other geographical regions at corresponding latitudes. In contrast to the antarctic ozone hole, which occurs regularly both on a spatial and a temporal scale (Hofmann et al. 1992, Davidson \& van der Heijden 2000), the arctic ozone hole seems to occur irregularly (Stamnes et al. 1988, Jokela et al. 1993). The radiation levels within both the visible and the UV bands decrease with increasing latitude due to the increase in the solar zenith angle. Because the UV-B radiation is normally low at high latitudes, abrupt increases in the UV-B radiation caused by irregular occurrences of ozone holes may have a large impact on the biota, since it is not adapted to such high UV-B radiation levels.

Radiation at wavelengths within the UV-A band ( 320 to $400 \mathrm{~nm}$ ) is only weakly attenuated by ozone, and therefore this part of the spectrum will not be influenced by reductions in ozone concentrations. A reduction in the primary production due to enhanced UV-B radiation has been reported for the waters surrounding Antarctica during the occurrence of an ozone hole, with ozone concentrations decreasing from 300 to <200 DU (Dobson unit) (Smith et al. 1992, Holm-Hansen et al. 1993a, Neale et al. 1998b). There are numerous reports confirming that increased UV-B radiation could be deleterious to single components of the marine food web (Holm-Hansen et al. 1993b, Keller et al. 1997, Zagarese \& Williamson 2000, Vernet 2000), and that concomitant nutrient limitation may result in higher sensitivity of phytoplankton to increased UV-B radiation levels (Lesser et al. 1994). However, when considering the effects of ozone depletion, some authors emphasise the importance of a more holistic view. Laurion et al. (1998) found that the effect of increased levels of incident UV-B radiation was low on the plankton community of a mesotrophic lake in Ontario, Canada, while Browman et al. (2000) found that the direct effects of increased UV-B radiation exposure to marine crustacean zooplankton in the Gulf of St. Lawrence in Canada were small compared to all other environmental stress factors. Still more unexpected were the findings of Arrigo (1994), obtained by coupling a bio-optical model for phytoplankton production to a detailed radiative transfer model. His findings showed that reduced levels of ozone resulted not only in higher transmission of UV-B radiation, but also of PAR (photosynthetically active radiation). He concluded that in early spring in the Southern Ocean (i.e. at high solar zenith angles) a 50\% reduction in stratospheric ozone would enhance the primary production in the euphotic zone, since the advantage of increased PAR was more important to primary production than the disadvantage of increased levels of UV-B radiation. Hessen (2002) proposes that firm conclusions about increased levels of UV radiation (UVR) in the Arctic and possible overall food-web effects should be avoided, due to lack of data.

Under normal atmospheric conditions, organisms being exposed to UVR have numerous mechanisms to protect themselves (Holm-Hansen et al. 1993b, Roy 2000). But the degree of damage to phytoplankton caused by increased UV-B radiation is not only a matter of physiological and morphological protection mechanisms. The presence of dissolved UVR-absorbing constituents in the water, like coloured dissolved organic matter (yellow substance) (Gibson et al. 2000), may lead to considerable changes in the penetration depths of UV-A radiation, UV-B radiation and PAR, which in turn may reduce the degree of damage to phytoplankton. In addition, many phytoplankton species have the possibility of avoiding devastating levels of UV-B radiation at the surface by downward vertical displacement. Thus, in accordance with Neale et al. (1998b), the UVR tolerance of phytoplankton is highly dependent on the depth of the mixed-layer. Barbieri et al. (2002) found that the depth of the upper mixedlayer must approach the depth of the euphotic zone to minimise UVR-induced damage to phytoplankton. In Norwegian open ocean waters the mixed-layer depth is regulated by the degree of heating of the upper layer of the water column and the turbulence created by wind. In fjords, the freshwater supply together with tidal and/or horizontal advection, which are driven either by coastal winds (Erga \& Heimdal 1984, Erga 1989a, Sætre et al. 1988) or density fluctuations in the coastal water (Aure et al. 1996), regulate vertical mixing.

Højerslev \& Aas (1991) and Aas \& Højerslev (2001) presented measurements of the UV $310 \mathrm{~nm}$ attenuation in the waters of the Norwegian Sea and at selected stations in North European coastal waters for the period from 1967 to 1981. Also, Aas \& Høkedal (1996) presented measurements of the UV $306 \mathrm{~nm}$ attenuation in the waters around Svalbard. However, more comprehensive data sets representing the whole underwater UV spectrum are generally scarce for high-latitude North Atlantic waters (Vasseur et al. 2003). Common to most of these waters is therefore the lack of knowledge about normal and abnormal UV-A and UV-B radiation levels at different depths of the water column. Such information is a prerequisite for conducting realistic effect studies on different phyto- 
plankton species. It is also important to have the best possible and complete data in order to develop and test marine bio-optical models.

Here, we present underwater UVR data at 305, 320, 340 and $380 \mathrm{~nm}$, as well as for the PAR spectral band, together with natural fluorescence (683 nm) in openocean, coastal and fjord waters. The relative contributions of chlorophyll a ( $\mathrm{chl}$ a) and coloured dissolved organic matter (CDOM) to the attenuation of UVR downwards in the water column are also given. Data on UVR effects on primary production and vertical distribution of phytoplankton are presented and discussed. As far as we know, such a combination of data has not yet been presented for Norwegian marine waters. The present data set is representative of western Norwegian coastal and fjord waters, the Greenland Sea and the northern Norwegian Sea.

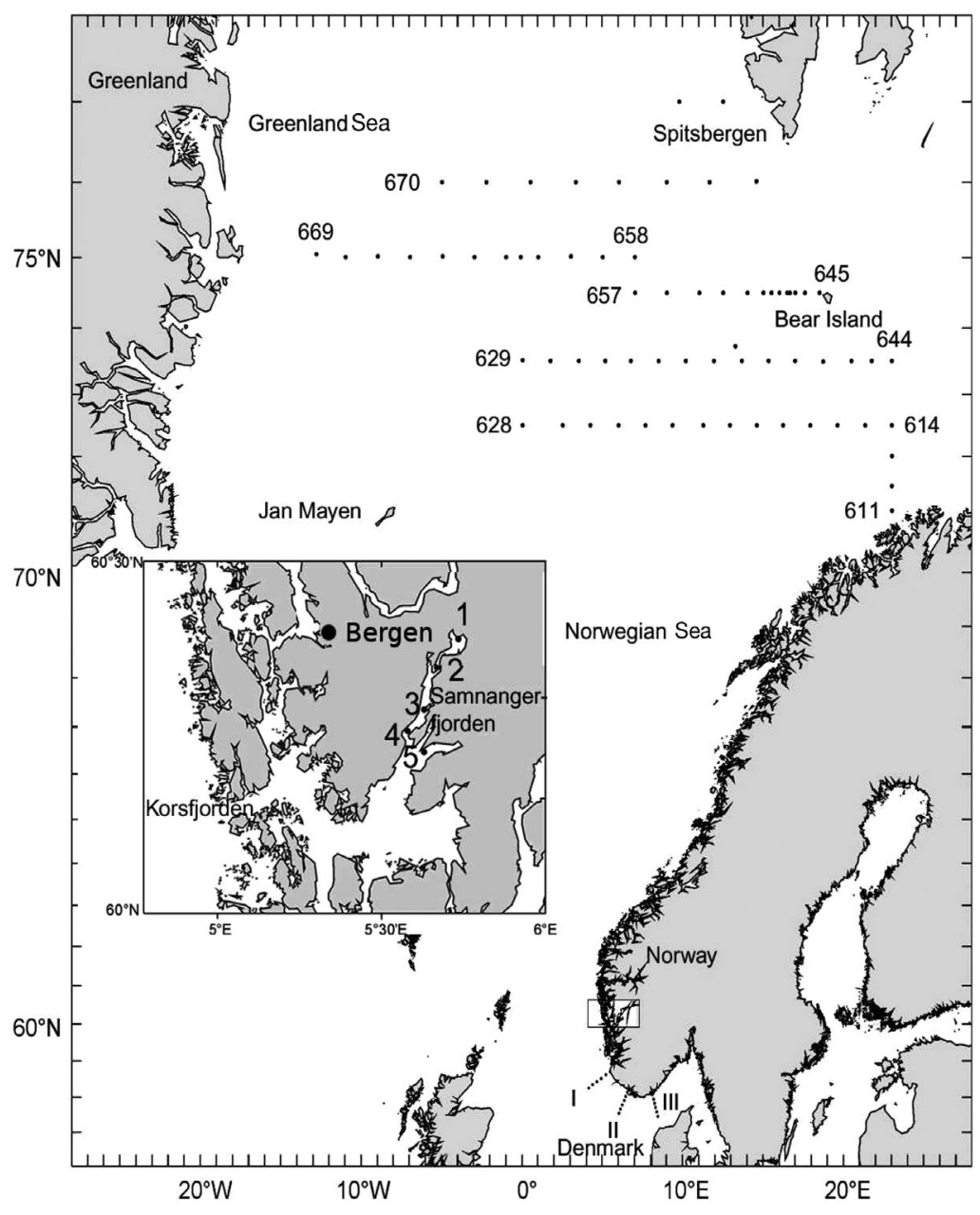

Fig. 1. Map of the 3 investigation areas. The Greenland and Norwegian Seas (GNS, 29 July to 15 August in 1993 and 1996, numbered stations from 611 to 679 ); coastal waters of south-western Norway (SWN, 5 to 10 May 2001, Transects I, II and III); and the Samnanger fjord (SAF, inset, March 1999 to January 2000, numbered stations from 1 to 5)

\section{MATERIALS AND METHODS}

Study area. In situ data were collected during 3 cruise periods. In the period 29 July 1993 to 15 August 1993 sampling was carried out onboard the RV 'Johan Hjort' along transects in polar waters covering stations from northern Norway via the east coast of Greenland to the west coast of Spitsbergen (Fig. 1). An additional cruise was performed in the same area and during the same seasonal period in 1996. The investigated area thus comprises both the Greenland Sea and the Norwegian Sea (GNS). From March 1999 to January 2000 a full program of data sampling was conducted on 12 cruises with the RV 'Hans Brattstrøm' in the Samnanger fjord (SAF), western Norway. Here, the investigations were carried out at 3 main stations (Stns 1, 3 and 5). In addition, 2 stations (Stns 2 and 4) were visited for a reduced sampling program. Another reduced sampling program was carried out on a cruise on 12 to 13 November at the 3 main stations (Fig. 1). During the period 5 to 10 May 2001 the coastal waters of south-western Norway (SWN) and the Skagerrak were investigated onboard the RV 'Håkon Mosby'. Measurements were done along 3 transects (I, II and III), from the inner coast of SWN and outwards, crossing the 'Norwegian Coastal Current' (NCC). A 4th cruise track was obtained by drifting along the coast in the NCC from Transect III back to Transect I. Wind data were obtained from the Norwegian Meteorological Institute.

Salinity and temperature. At each station depth profiles of temperature and salinity were measured with a Sea Bird 911 CTD probe. Water samplers were mounted on the CTD.

Light measurements. Depth profiles of underwater UVR in narrow spectral bands centred at wavelengths of 305, 320, 340 and $380 \mathrm{~nm}$, and in the PAR (400 to $700 \mathrm{~nm}$ ) band together with natural, solar-induced fluorescence were obtained with a PUV 500 from Biospherical Instruments (San Diego, USA). The diffuse attenuation coefficient for downwelling irradiance $K_{\mathrm{d}}$ is given by:

$$
K_{\mathrm{d}}=\frac{1}{z_{1}-z_{0}} \ln \left(\frac{E\left(z_{0}\right)}{E\left(z_{1}\right)}\right)
$$

where $z_{0}$ and $z_{1}$ are 2 different depths and $E$ is the irradiance. To be able to include a maximum number of $305 \mathrm{~nm}$ measurements, we chose $z_{0}$ to be just below the surface and $z_{1}$ to be 5, 3 and $1 \mathrm{~m}$ in the GNS, SWN and 
SAF waters, respectively. $K_{\mathrm{d}}$ values were obtained by linear regression on the log-transformed irradiance profiles between $z_{0}$ and $z_{1}$, containing $>40$ data points. The $1 \%$ light attenuation depths were calculated from Eq. (1). Extrapolation of the PAR attenuation curve to calculate the $1 \%$ light depth is not accurate, since light at the different wavelengths comprising the PAR is not depth-attenuated at the same rate. Thus, $K_{\mathrm{d}}$ (PAR) varies with depth even in well-mixed waters. This is not the case for attenuation of narrow UVR bands in well-mixed waters. To enable us to use the same procedure for all $4 \mathrm{UV}$ channels, we chose to extrapolate from the upper part of the UVR attenuation curve. Therefore, our 1\% UVR attenuation depths probably represent minimum estimates. Unfortunately, a surface unit for simultaneous measurements of on-deck values within the same UVR bands as those of the underwater unit was not always at our disposal. To compensate for this, downward and upward profiles were taken at each station, and only data from stations where downward and upward profiles were in close agreement were included in our material. Special care was taken to lower and raise the instrument slowly in order to obtain accurate readings of UVR at $305 \mathrm{~nm}$. The PUV 500 was kept in the water for 15 min prior to measurements to stabilise the temperature of the detectors, and measurements were adjusted for dark current both before and after each profile in accordance with the procedure given in Kjeldstad et al. (2003). This temperature-adaptation procedure together with very slow lowering and raising is very important for obtaining stable readings, especially in the $305 \mathrm{~nm}$ channel. The UVR measurements were compared with data computed by the CAO-DISORT (Coupled Atmosphere-Ocean Discrete-Ordinate Radiative Transfer) model (see below). Our PUV was part of an inter-comparison campaign for underwater radiometers conducted along a transect in the Samnanger fjord during the period 26 to 30 April 1999 (Kjeldstad et al. 2003). During the GNS cruises we recorded PAR irradiances at the surface with a LICOR LI-190 S quantum sensor, positioned in a gyro frame at the top of the mast and coupled to a LICOR integrator.

Nutrients. Dissolved inorganic nutrients (nitrate, nitrite, orthophosphate and silicate) were analysed according to standard methods (Parsons et al. 1992) adapted to an auto-analyser (Rey et al. 2000).

Chlorophyll a. Samples for chl a analysis were filtered onto $\mathrm{GF} / \mathrm{F}$ filters and stored at $-20^{\circ} \mathrm{C}$, and analysed within $2 \mathrm{wk}$. The analyses were done fluorometrically (Turner Designs-10) according to HolmHansen et al. (1965), using $90 \%$ acetone as solvent and acid corrections for phaeopigments. In some cases chl $a$ within the size fractions 1 to 5,5 to 10 and $>10 \mu \mathrm{m}$ were obtained by filtering water samples through 1 ,
5 and $10 \mu \mathrm{m}$ Poretics polycarbonate membrane filters. The depth of the maximum chl a concentration was recognised by in situ fluorescence profiles conducted by a SeaTech fluorometer in the GNS and a Sea Point fluorometer in the SWN and SAF.

Coloured dissolved organic matter. Water samples for measurements of CDOM (i.e. yellow substance) were collected at 3 different depths (1, 10 and $50 \mathrm{~m}$ ), filtered through a $0.2 \mu \mathrm{m}$ Nucleopore filter and stored in opaque glass bottles at $4^{\circ} \mathrm{C}$ for a few days before they were analysed according to a procedure given by Højerslev \& Aas (1998). Absorbance was normally measured between 250 and $750 \mathrm{~nm}$ (in some cases the upper wavelength was $650 \mathrm{~nm}$ ) using a $10 \mathrm{~cm}$ quartz cuvette in a Shimadzu MPS 2000 spectrometer. Pure water (MILLI-Q) was used as reference. It was assumed that the filtered seawater was dominated optically by CDOM, although particles less than the pore size of the filter may influence the results (Aas 2000). The absorbance values from the $10 \mathrm{~cm}$ cuvette measurements were then converted to absorption coefficients as described in Frette et al. (2004). The absorption coefficient at $310 \mathrm{~nm}, \mathrm{a}_{\mathrm{y}}(310)$, was used as a measure of the CDOM concentration. A constant value for the baseline correction was used, equal to the observed value of $a_{\mathrm{y}}$ in the red part of the spectrum (Højerslev \& Aas 2001). Due to practical problems, samples for CDOM analysis were not taken in the GNS, only in SWN and SAF waters. The exponential decay factor $S$, also referred to as the 'CDOM spectral slope', was calculated for the spectral interval between 275 and $425 \mathrm{~nm}$. All readings at $425 \mathrm{~nm}$ were consistently above zero. The $S$ value was used to identify the type or origin of the CDOM; it is normally constant for a certain water type. For further details, see Hamre et al. (2003), Kjeldstad et al. (2003) and Frette et al. (2004).

Particulate organic carbon. This biomass parameter was analysed in a Carlo-Erba CHN analyser. No corrections were made for detritus.

Coupled Atmosphere-Ocean Discrete-Ordinate Radiative Transfer Model. UV irradiances just below the surface were calculated using a CAO-DISORT model. The calculations were conducted for 2 different weather conditions (clear and cloudy) and for ozone densities of 200 and 400 DU. A detailed description of the CAO-DISORT model is available in Jin \& Stamnes (1994) and Hamre et al. (2004). The CAO-DISORT model has been extensively tested both against other deterministic radiative transfer codes as well as against stochastic Monte Carlo codes (Mobley et al. 1993, Gjerstad et al. 2003).

Primary production. Calculations of photosynthetic rates were based upon measurements of natural fluorescence, modelling based on measured PAR and UVR 
and ${ }^{14} \mathrm{C}$-uptake. Primary production, measured as carbon assimilation rates, was obtained from in situ incubations at Stn 3 in the SAF and from laboratory incubations of water samples taken at a depth of $10 \mathrm{~m}$ at 3 stations in the SWN. The measurements in the SAF were conducted in accordance with the ${ }^{14} \mathrm{C}$-method (Steemann Nielsen 1952), with $100 \mathrm{ml}$ quartz (UVR transparent) and glass bottles (not UVR transparent) suspended at the sampling depths for $24 \mathrm{~h}$. The incubations were started between 11:00 and 12:00 h UTC.

During the GNS-1996 cruise, primary production was measured both by ${ }^{14} \mathrm{C}$-incubations and natural fluorescence. Samples were collected from several depths in the water column in order to obtain representative samples from the upper mixed-layer, the pycnocline and waters below the pycnocline. In this case, a $P$ vs. $E$ incubator, equipped with a metal halide daylight lamp (OSRAM HQI-T 400/DH) providing 16 different irradiances from 0 to $700 \mu \mathrm{mol} \mathrm{m}{ }^{-2} \mathrm{~s}^{-1}$ by means of neutral filters, was used to measure carbon assimilation rates. The incubator was cooled with subsurface seawater from the ships' water intake. Samples were incubated for about $2 \mathrm{~h}$ in $25 \mathrm{ml}$ glass bottles. UVR data were not available for the GNS-1996 cruise, and thus the carbon assimilation measurements were only used to validate the fluorescence model in this case. The ${ }^{14} \mathrm{C}$-measurements in SWN waters were performed following the same procedure as for the corresponding measurements during the GNS-1996 cruise.

After incubations, both in situ and on board, the samples were filtered (GF/F or $0.45 \mu \mathrm{m}$ membrane filters) and frozen immediately for later analysis ashore. For all incubations commercially available radioactive carbon was used (DuPont NEN Sodium bicarbonate NEC086S, $20 \mu \mathrm{Ci}$ ). Ashore the samples were acidified, and the radioactivity was measured with a Tri-Carb scintillation counter using the channel ratio method for determining quenching. For the GNS-1996 cruise the $P$ vs. $E$ curve parameters were calculated using the equation of Platt et al. (1980). These parameters were then used together with the measured PAR values to calculate carbon assimilation rates. Hourly values of photosynthetic rates for the SAF were obtained by dividing the daily values of carbon assimilation by the length of the light period. The carbon assimilation rates obtained for the GNS, SWN and SAF waters were later correlated with the rates derived from the natural fluorescence of chl $a$, according to the procedure given by Chamberlin \& Marra (1992) (see below). For the SWN waters, however, only a local adaptation of the model was possible, since few carbon assimilation data were available.

Values for natural fluorescence throughout the water column were obtained by using a PUV 500 with a channel for measurement of upward radiance at $683 \mathrm{~nm}$, the peak emission wavelength for chl a fluorescence. Primary production was obtained from natural fluorescence by means of the equation:

$$
F_{\mathrm{c}}(t, z)=\left(\frac{\varphi_{\mathrm{c}}}{\varphi_{\mathrm{f}}}\right)_{\max } \cdot\left(k_{T} \cdot T+C\right) \cdot \frac{k_{\mathrm{E}}}{k_{\mathrm{E}}+E_{0}(\mathrm{PAR}, t, z)} \cdot F_{\mathrm{f}}(t, z)
$$

given by Chamberlin \& Marra (1992). Here, $F_{\mathrm{c}}$ is the rate of photosynthesis, while $F_{\mathrm{f}}$ is the rate of fluorescence. $F_{\mathrm{f}}$ can be calculated from the measured nadir radiance $L_{\mathrm{u}}(683, z)$ and the measured $K_{\mathrm{PAR}}$ using the formula $F_{\mathrm{f}}=4 \pi L_{\mathrm{u}}(683, z)\left[a(683, z)+K_{\mathrm{PAR}}\right]$, where $a(683, z)$ is the absorption coefficient at $683 \mathrm{~nm}$ at depth $z$. The units of $F_{\mathrm{c}}$ and $F_{\mathrm{f}}$ are the number of carbon atoms and photons, respectively, per cubic metre per second. For convenience we use the alternative unit for $F_{\mathrm{c}}$ : production in $\mathrm{mg} \mathrm{C} \mathrm{m} \mathrm{m}^{-3} \mathrm{~h}^{-1}$. The ratio of $F_{\mathrm{c}}$ to $F_{\mathrm{f}}$ depends on the temperature $T$ and the available scalar PAR irradiance $E_{0}(\mathrm{PAR})$. The PUV 500 instrument measured the downwelling irradiance, and we converted from downwelling irradiance to scalar irradiance through multiplication by a conversion factor of 1.4, which CAO-DISORT simulations of the light field showed to be reasonable at depths $>5 \mathrm{~m} . \varphi_{\mathrm{c}}$ is the quantum yield for photosynthesis, $\varphi_{\mathrm{f}}$ is the quantum yield for fluorescence and $\left(\varphi_{\mathrm{c}} / \varphi_{\mathrm{f}}\right)_{\max }$ is the maximum ratio between these 2 quantum yields measured under low light conditions. The quantity $k_{T}$ is the slope of the regression between temperature and $\varphi_{\mathrm{c}} / \varphi_{\mathrm{f}}$, and $C$ is the intercept of this regression, while $k_{\mathrm{E}}$ is an empirical constant equal to the value of $E_{0}(\mathrm{PAR})$ for which the ratio $\left(\varphi_{\mathrm{c}} / \varphi_{\mathrm{f}}\right)_{\max }$ attains half of its maximum value. We determined the values of $\left(\varphi_{\mathrm{C}} / \varphi_{\mathrm{f}}\right)_{\max }$ and $k_{\mathrm{E}}$ based on the data available for the 3 different study areas, as discussed below. In addition, we used $k_{T}=0.044{ }^{\circ} \mathrm{C}^{-1}$ and $C=0.257$, which were the values that gave the best overall fit to the data of Chamberlin \& Marra (1992).

The potential for inhibition of primary production due to UV radiation (Cullen et al. 1992) can be accounted for by means of an inhibition factor $f\left(E^{*}\right)$, which is estimated from UVR measurements. It describes the expected reduction in biomass production caused by UV radiation and is given by $f\left(E^{*}\right)=1 /\left(1-E^{*}\right)$, where:

$$
E^{*}=\int_{280}^{400} \varepsilon\left(\lambda_{i}\right) E_{0}\left(\lambda_{i}\right) \mathrm{d} \lambda
$$

with $\varepsilon(\lambda)$ being a biological weighting function (BWF). Since we measure the UVR at discrete spectral wavelengths, we use the approximation:

$$
E^{*}=\sum_{i=1}^{n} \varepsilon\left(\lambda_{i}\right) E_{0}\left(\lambda_{i}\right) \Delta \lambda
$$

where $\lambda_{i}(i=1,2,3,4)$ are the wavelengths at which the UVR is measured. We let $\varepsilon\left(\lambda_{i}\right)$ represent the mean 
value of $\varepsilon(\lambda)$ within each interval according to the formula

$$
\varepsilon\left(\lambda_{i}\right)=\int_{\lambda_{i}}^{\lambda_{i+1}} \varepsilon(\lambda) \mathrm{d} \lambda / \Delta \lambda
$$

From spectra simulated with the CAO-DISORT model we found that the approximation in Eq. (4) yields an error $<5 \%$ as long as the inhibition is significant $\left(E^{*}>\right.$ 0.01). As a representation of the BWF we used the average of 3 different BWFs measured by Cullen \& Neale $(1994,1997)$. Based on simulated spectra (for $E^{*}>0.01$ ) we found the most UV-sensitive BWF to give an inhibition that was about $50 \%$ higher than the inhibition produced by the average BWF. Similarly, we found the least UV-sensitive BWF to give an inhibition that was about $50 \%$ lower than the average BWF (for $E^{*}>0.01$ ). The inhibition presented here should therefore not be interpreted as the actual inhibition but as a possible inhibition caused by the amount of UVR available.

The production per gram chl a (i.e. the photosynthetic efficiency) obtained from model calculations was based on a functional relationship between incident light and photosynthesis, according to the parameterisation given by Neale et al. (1998a):

$$
P^{\mathrm{B}}=P_{\mathrm{s}}^{\mathrm{B}}\left(1-\mathrm{e}^{-E_{\mathrm{PAR}} / E_{\mathrm{s}}}\right) f\left(E^{*}\right)
$$

Here, $P^{\mathrm{B}}{ }_{\mathrm{s}}\left(\mathrm{g} \mathrm{C} \mathrm{g}^{-1} \mathrm{chl} a \mathrm{~h}^{-1}\right)$ is the maximum photosynthesis in the absence of photo-inhibition. It is found by minimising the difference between the production per gram chl a derived from fluorescence and the production per gram chl a predicted by Eq. (6). $E_{\mathrm{PAR}}$ ( $\mu \mathrm{mol}$ photons $\mathrm{m}^{-2} \mathrm{~s}^{-1}$ ) is the PAR irradiance, and $E_{\mathrm{s}}$ ( $\mu \mathrm{mol}$ photons $\mathrm{m}^{-2} \mathrm{~s}^{-1}$ ) is a characteristic irradiance value describing the saturation of photosynthesis as $E_{\mathrm{PAR}}$ increases. The reason for choosing a model for the photosynthesis that depends on $E_{\mathrm{PAR}}$ rather than doses is that we measured the UV irradiances only at a specific time of the day, implying that doses were not available. This choice is justified provided there is a balance between damage and repair. Simultaneous UVR and Cassimilation measurements were not available for the GNS and SWN waters. Therefore, the modelled primary production was correlated with measured carbonassimilation rates only for the fjord waters of the SAF.

In order to use Eq. (2) to calculate the production, we must determine the parameters $k_{\mathrm{E}}$ and $\left(\varphi_{\mathrm{c}} / \varphi_{\mathrm{f}}\right)_{\text {max }}$, which are specific to each study area. Similarly, in order to use Eq. (6) to calculate the production, we must determine the parameters $P^{\mathrm{B}}$ and $E_{\mathrm{s}}$. Depending on which data were available, we used different methods to determine these parameters for the 3 study areas. For the SAF we determined the parameters directly by minimising the difference between the results obtained using either Eq. (2) or (6), and the ${ }^{14} \mathrm{C}$-assimilation data. For the GNS we used the same values for $k_{\mathrm{E}}$ and $\left(\varphi_{\mathrm{C}} / \varphi_{\mathrm{f}}\right)_{\max }$ as found during the GNS-1996 cruise. Then $P^{\mathrm{B}}$ and $E_{\mathrm{s}}$ were determined by minimising the difference between the ${ }^{14} \mathrm{C}$-assimilation data and the results obtained using Eq. (2) or (6). In the SWN we measured the maximum photosynthesis $P^{\mathrm{B}}$ at Stns 3 and 6 on Transect I and Stn 3 on Transect III and found the $P^{\mathrm{B}}$ s values to be 3.7, 2.2 and $3.4 \mathrm{~g} \mathrm{C} \mathrm{g}^{-1} \mathrm{chl} \mathrm{a} \mathrm{h}^{-1}$, respectively. We used the average value of $P^{\mathrm{B}}{ }_{\mathrm{s}}=3.1 \mathrm{~g} \mathrm{C} \mathrm{g}^{-1} \mathrm{chl} \mathrm{a} \mathrm{h} \mathrm{h}^{-1}$. To put another constraint on the evaluation of the 3 remaining parameters we chose to use the value $k_{\mathrm{E}}=182 \mu \mathrm{mol}$ photons $\mathrm{m}^{-2} \mathrm{~s}^{-1}$ for SWN waters, which is the mean value obtained from the data presented by Chamberlain \& Marra (1992). They found that the value for $k_{\mathrm{E}}$ varied little between different cruises. Using the procedures discussed above, we obtained the parameter values for the 3 different study areas shown in Table 1.

The PUV 500 instrument recorded data continuously. At the same time chlorophyll samples were taken at discrete depths. To determine the variation of $K_{\mathrm{d}}$ with chl $a$, we used chl a values from a depth of $0.5 \mathrm{~m}$. In order to obtain an approximate, continuous vertical profile of chl $a_{\text {, }}$ we interpolated linearly between the discrete sampling depths. The natural fluorescence data were used only at depths $>5 \mathrm{~m}$ to avoid the influence of the ambient red light.

Phytoplankton abundance. Microscopic enumeration and classification of phytoplankton were carried out through the application of the sedimentation method of Utermöhl (1931) to natural samples preserved by neutralised formalin.

\section{RESULTS}

\section{Hydrographical regimes and circulation patterns}

Data from the main transect Bear Island-eastern Greenland (Stns 645 to 669) in the GNS, from Transect

Table 1. Parameters of natural fluorescence-photosynthesis relationships for the 3 investigation areas GNS-1996, SWN and SAF. $\left(\varphi_{\mathrm{c}} / \varphi_{\mathrm{f}}\right)_{\max }$ is the maximum ratio between quantum yields of photosynthesis $\left(\varphi_{\mathrm{c}}\right)$ and fluorescence $\left(\varphi_{\mathrm{f}}\right)$ measured under low light, $k_{\mathrm{E}}$ is an empirical constant equal to the value of $E_{0}(\mathrm{PAR})$, where the ratio $\left(\varphi_{\mathrm{c}} / \varphi_{\mathrm{f}}\right)_{\max }$ is half of its maximal value, $P^{\mathrm{B}}$ is the maximum photosynthesis in the absence of photo-inhibition and $E_{\mathrm{s}}$ is a characteristic value for saturation

\begin{tabular}{|c|c|c|c|}
\hline Parameter & GNS & SWN & SAF \\
\hline$\left(\varphi_{\mathrm{c}} / \varphi_{\mathrm{f}}\right)_{\max }$ (carbon atoms per photon) & 0.59 & 1.62 & 0.96 \\
\hline$k_{\mathrm{E}}\left(\mu \mathrm{mol}\right.$ photons $\left.\mathrm{m}^{-2} \mathrm{~s}^{-1}\right)$ & 155 & 182 & 215 \\
\hline$P_{\mathrm{s}}^{\mathrm{B}}\left(\mathrm{gC} \mathrm{g}^{-1} \mathrm{chl} \mathrm{h} \mathrm{h}^{-1}\right)$ & 0.74 & 3.1 & 1.1 \\
\hline$E_{\mathrm{s}}\left(\mu \mathrm{mol}\right.$ photons $\left.\mathrm{m}^{-2} \mathrm{~s}^{-1}\right)$ & 46 & 90 & 42 \\
\hline
\end{tabular}
by PAR, $E_{\mathrm{PAR}}$ 
II in the SWN waters and from Stn 3 in the SAF (Fig. 1) were chosen to be representative for each of the 3 investigated areas. The GNS outside the west coast of Bear Island is characterised by a north-flowing surface current, which brings arctic water from the northern Barents Sea around the south-eastern point of the island (Olsen et al. 2003). On our cruise this water type was identified at Stns 645 to 647 by surface temperatures $<2{ }^{\circ} \mathrm{C}$ and surface salinities within the range from 33.8 to 34.5 (Fig. 2). Further to the west, the West Spitsbergen Current brings warmer water $\left(7\right.$ to $\left.9^{\circ} \mathrm{C}\right)$ of Atlantic origin (salinity $>35$ ), extending northwards from Stn 653 to 658. Typically the Greenland Sea surface temperatures ranged from 3.0 to $7^{\circ} \mathrm{C}$, and surface salinities ranged from 34.5 to 35.0 (Stns 659 to 668 ). In the western part of the Greenland Sea, the East Greenland Current brings arctic water, characterised by surface temperatures $<0^{\circ} \mathrm{C}$ and surface salinities around 31.0 at Stn 669, southwards from the Fram Strait. The Polar Front, at a depth of $100 \mathrm{~m}$, was revealed by temper- atures $<3.0^{\circ} \mathrm{C}$ and salinities $<35.0$ at Stn 657 (for further details see Rey et al. 2000). The mixed-layer depth varied between 20 and $40 \mathrm{~m}$ (Fig. 2). Both nitrate and silicate were almost depleted in the upper 10 to $20 \mathrm{~m}$ layer in the central Greenland Sea, but eastwards towards Bear Island nutrients increased slightly (Rey et al. 2000). The nitracline was situated at a depth of $25 \mathrm{~m}$.

On the SWN cruise, northerly winds dominated along Jæren (the coastline between Transects I and II) during the period 3 to 9 May. This normally leads to a displacement of NCC waters away from the coast (Sætre et al. 1988). Outside the fjord system this displacement results in a divergent zone where coastal surface water connects directly with the intermediate layer of the fjord, and it is accompanied by coastal upwelling, which leads to a rapid outflow of the upper layer (separated most of the year from deeper strata by a well-defined pycnocline) of the fjords into NCC waters. The upwelling was accompanied by maximum nutrient concentrations at Stn 1 on Transect I, with

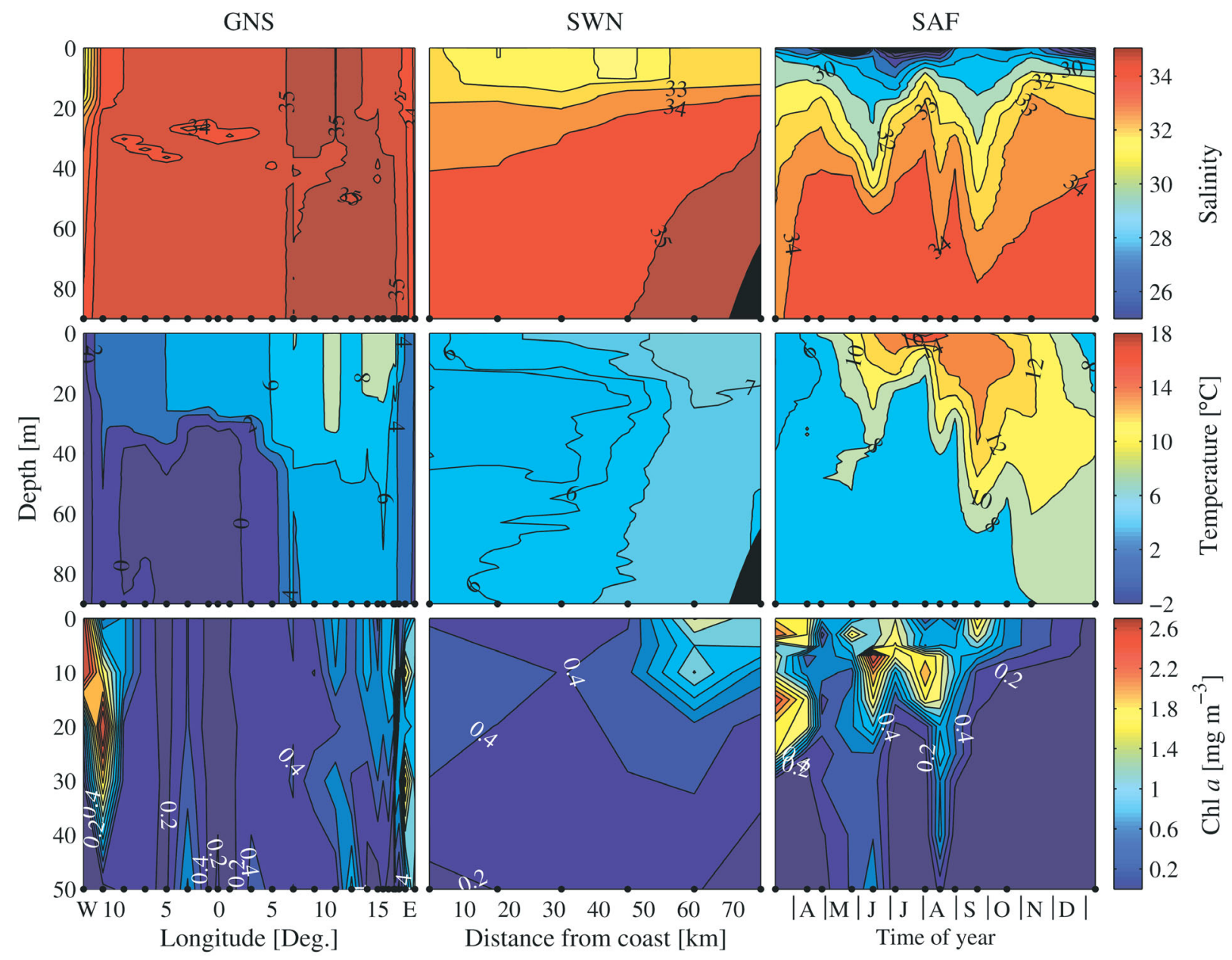

Fig. 2. Isopleth diagrams for salinity, temperature $\left({ }^{\circ} \mathrm{C}\right)$ and $\mathrm{chl}$ a $\left(\mathrm{mg} \mathrm{m}^{-3}\right)$ for the 3 investigation areas GNS-1993 (transect Bear Island-East Greenland), SWN (Transect II) and SAF (Stn 3). Note the different depth scale for chl a 
nitrate, silicate and phosphate concentrations at a depth of $10 \mathrm{~m}$ of $9.0,4.5$ and $0.7 \mu \mathrm{M}$, respectively. These values were more than twice as large as those observed on the remaining part of the transect, and higher than all other values found at a depth of $10 \mathrm{~m}$ during the SWN cruise. By such mechanisms CDOM and fjord phytoplankton may be transported far away from the coast, while coastal phytoplankton may be advected into the fjord system from the NCC by the inflowing compensation current. In addition, the NCC receives CDOM from river mouths close to the coast in the Skagerrak area, from the Kattegat and the Baltic Sea and from the German Bight by the Jutland Coastal Current (Aure et al. 1998).

Our data from Transects II and I show that after leaving the Skagerrak the main core of the NCC water was encountered between Stns 2 and 4. On Transect II this encounter occurred between 17 and $46 \mathrm{~km}$ offshore (Fig. 2), and on Transect I it occurred between 28 and $67 \mathrm{~km}$ offshore. On Transects I, II and III, the mixedlayer depth in the core of the NCC water extended down to depths of about 15, 10 and $7 \mathrm{~m}$, respectively. In the core of the NCC waters nitrate was $<2.5 \mu \mathrm{M}$, while silicate and phosphate concentrations were $<2$ and $0.3 \mu \mathrm{M}$, respectively. Atlantic water was recognised at a depth of $30 \mathrm{~m}$ at the outermost station (Stn 6) on Transects I and II.

In the SAF, inflow and downwelling events during periods of southerly winds, as well as outflow and upwelling events during periods of northerly winds, were found to be the driving forces for the horizontal and vertical advection of phytoplankton (see Frette et al. 2004). Such events are consistent with water exchanges found in other nearby fjords (Erga \& Heimdal 1984, Erga 1989a). Common to all these fjords is the inflow of coastal water in the upper layer during March, introducing the main spring bloom of diatoms, and the outflow of fjord water in the upper layer in April. The inflowing compensation current in the intermediate layer, associated with the April event, gives rise to upwelling of nutrient-rich deep water in the fjord. For the rest of the year the inflow and outflow events are more variable.

Current measurements at Straumsneset in the SAF, close to Stn 2 (Fig. 1), during the period 14 June to 7 July showed that in the depth interval 5 to $30 \mathrm{~m}$ the water transport varied between $1000 \mathrm{~m}^{3} \mathrm{~s}^{-1}$ inwards and $600 \mathrm{~m}^{3} \mathrm{~s}^{-1}$ outwards (Aure et al. 2000). During the measurement period approximately $80 \%$ of the total fjord water transport was directed inwards. Inflows of less saline coastal water occurred in the upper layer around mid-March, mid-June, mid-August and late September (Fig. 2). Among these events the mid-June and late September inflows were extensive and extended deeper at all stations. The inflowing water was colder than the fjord water during the first event and warmer during the others. Extensive outflows of less saline fjord water occurred in the upper layer in April and during the period early July to early August. These events resulted in upwelling of colder and more saline deep water at all stations in the fjord, as revealed by the fact that the $>34$ isohaline approached the 40 to $30 \mathrm{~m}$ depth level (Fig. 2). Outflow of more brackish and warm fjord water, accompanied by upwelling of colder and more saline deep water, was evident in late October. It was found that the mixed-layer depth in the SAF varied between 1 and $10 \mathrm{~m}$ throughout the year. In the SAF nutrient concentrations were low in the upper $10 \mathrm{~m}$ layer from mid-April until October. Mean values of nitrate, silicate and phosphate for this period were 0.4, 0.8 and $0.02 \mu \mathrm{M}$ (Aure et al. 2000).

\section{Phytoplankton}

Table 2 shows chl a concentrations at the depth of the chl a maximum for the particle size fractions of 1-5, 5-10 and $>10 \mu \mathrm{m}$ along the transect from Bear Island to East Greenland in the GNS. Close to the coast of East Greenland, the total chl a concentrations were highest $\left(2.5 \mathrm{mg} \mathrm{m}^{-3}\right)$, and large cells dominated by diatoms were found there. At the stations east of the East Greenland Current, the total chl a concentrations were $<0.5 \mathrm{mg} \mathrm{m}^{-3}$ (Fig. 2), and smaller cells (i.e. flagellates) contributed to a higher degree. Towards Bear Island the chl a concentrations increased to $1-1.5 \mathrm{mg}$ $\mathrm{m}^{-3}$. High chl a concentrations were found down to a depth of $30 \mathrm{~m}$ at the coast of East Greenland and Bear Island. Below a depth of $50 \mathrm{~m}$, the chl a concentrations were mostly $<0.2 \mathrm{mg} \mathrm{m}^{-3}$ (Rey et al. 2000). Averaging over all stations on the transect, we found the vertical distribution of chl a to have a maximum of $0.6 \mathrm{mg} \mathrm{m}^{-3}$ in the upper $10 \mathrm{~m}$ layer (Fig. 3). The average vertical distribution of phaeopigments had its maximum of $0.18 \mathrm{mg} \mathrm{m}^{-3}$ at a depth of $30 \mathrm{~m}$. Below a depth of $52 \mathrm{~m}$, the phaeopigment concentrations were higher than the chl a concentrations.

Table 2. Variations of chlorophyll a (chl a) concentrations within 3 different algal size fractions from 3 different water masses (stations) on the main transect (Bear Island-East Greenland) in the GNS-1993. Samples are taken from the depth of chl a maximum

\begin{tabular}{|lccc|}
\hline Station & \multicolumn{3}{c|}{$\begin{array}{c}\text { Chl } a\left(\mathrm{mg} \mathrm{chl} a \mathrm{~m}^{-3}\right) \\
5-10 \mu \mathrm{m}\end{array}$} \\
\hline 645 & $1-5 \mu \mathrm{m}$ & 0.04 & 0.13 \\
657 & 0.15 & 0.03 & 0.00 \\
669 & 0.26 & 0.19 & 2.08 \\
\hline
\end{tabular}




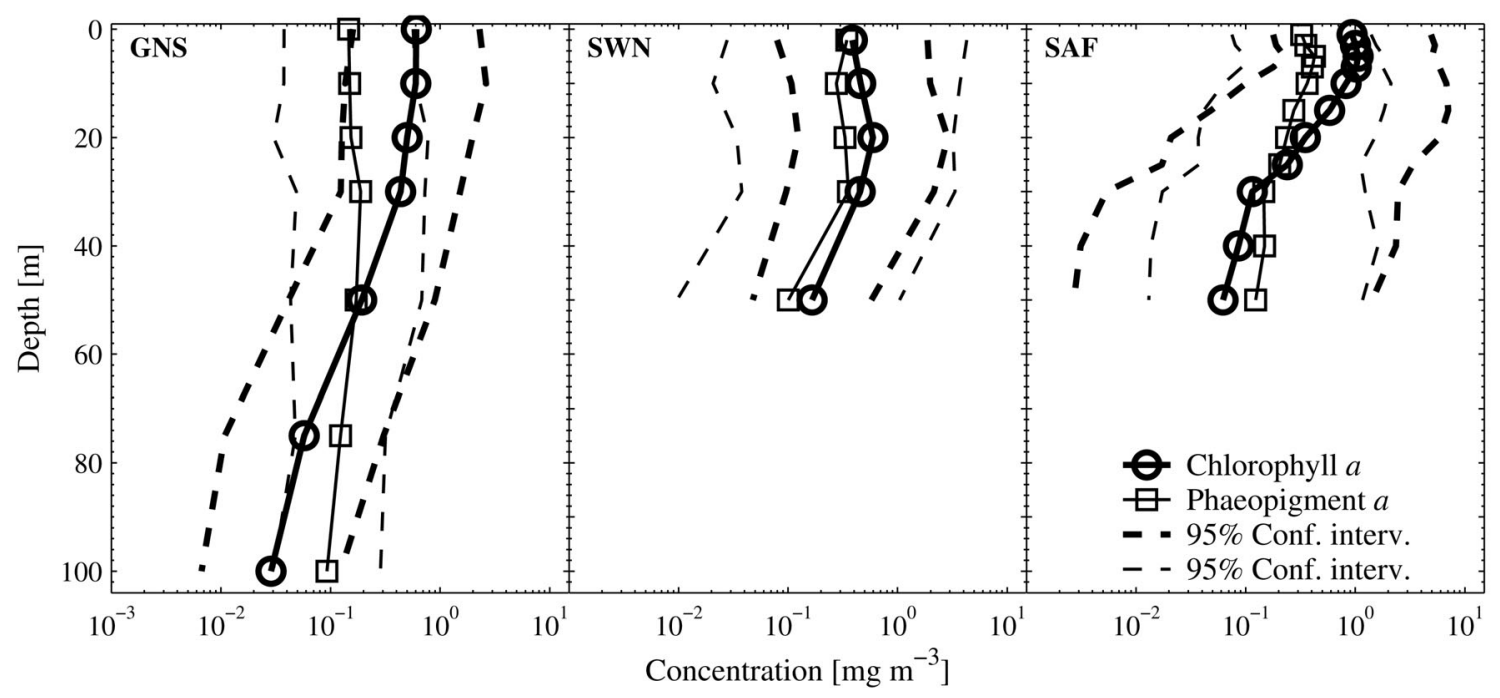

Fig. 3. Average vertical distribution of chl $a$ and phaeopigment $a$ concentrations for the 3 investigation areas GNS-1993, SWN and SAF. The $95 \%$ confidence intervals are indicated

The chl a concentrations on Transects I and II in SWN waters (Fig. 2) were $<1.0 \mathrm{mg} \mathrm{m}^{-3}$, except at the outer stations, where chl a concentrations of 2.1 and $1.6 \mathrm{mg} \mathrm{m}^{-3}$, respectively, were encountered near the surface. The shallowest vertical distribution of chl a was found on Transect II, while on Transect III the maximum concentration of chl a $\left(2.6 \mathrm{mg} \mathrm{m}^{-3}\right)$ was found in the middle of the transect at a depth of $20 \mathrm{~m}$. The average vertical distribution for all stations gave a chl a maximum of $0.6 \mathrm{mg} \mathrm{m}^{-3}$ at a depth of $20 \mathrm{~m}$ (Fig. 3). The average concentrations of phaeopigments were relatively high at all depths, indicating a postbloom situation in the NCC water mass. The maximum phaeopigment concentrations were found at the depths of 0 and $30 \mathrm{~m}$. Except at Stn 1 on Transect I, where the phytoplankton cell density was low, diatoms dominated in the inner parts of the transects, while flagellates and dinoflagellates dominated in the outer parts (J. Sazhin pers. comm.).

The phytoplankton development in the SAF was followed from March to January, but dominating classes and cell densities are presented here only for Stn 3. Two distinct blooms were encountered, the first being a bloom of the diatom Skeletonema costatum on 16 and 17 March (Fig. 4), which coincided with the annual maximum of chl a (Fig. 2). The highest chl a concentration $\left(6.3 \mathrm{mg} \mathrm{m}^{-3}\right)$ occurred at the outer station at a depth of $20 \mathrm{~m}$. But in March relatively high chl a concentrations were found down to a depth of $50 \mathrm{~m}$ $\left(2.6 \mathrm{mg} \mathrm{m}^{-3}\right)$ at Stn 5, and down to a depth of $15 \mathrm{~m}$ at Stns 3 and 1 (2.6 and $2.2 \mathrm{mg} \mathrm{m}^{-3}$, respectively). At Stn 1, on the other hand, a maximum chl a concentration of $5.4 \mathrm{mg} \mathrm{m}^{-3}$ was found at the surface. Microscopic investigations revealed the occurrence of rest- ing spores of Chaetoceros spp. and an impression of cells in a reduced physiological condition. Therefore the spring diatom bloom was probably close to its termination. In April the appearance of calanoid copepods and faecal pellets indicated that grazing contributed to the decline of the bloom. The next bloom in June was dominated by the coccolithophorid Emiliania huxleyi. Maximum chl a concentrations within the range 2.4 to $2.9 \mathrm{mg} \mathrm{m}^{-3}$ (Fig. 2) were encountered at all 3 stations in the upper $10 \mathrm{~m}$ layer of the water column. For the rest of the year the highest chl a concentrations in the SAF were found in the depth interval 0 to $15 \mathrm{~m}$ (Fig. 2), except at Stn 3 on 15 April and at Stn 1 on 20 October, where a chl a concentration of $1.7 \mathrm{mg} \mathrm{m}^{-3}$ was found at depths of 20 and $40 \mathrm{~m}$, respectively. The

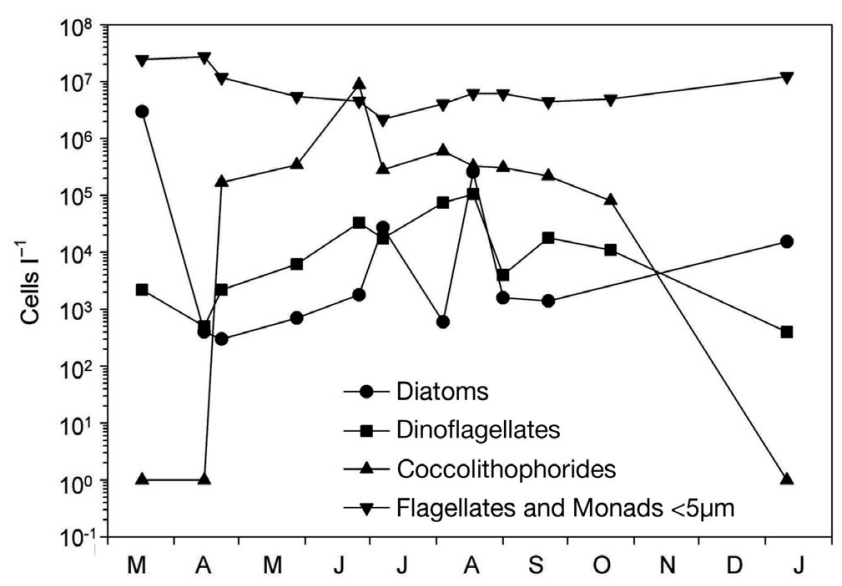

Fig. 4. Maximum cell concentrations within 4 main categories of phytoplankton in the SAF from March 1999 to January 2000. Samples were taken from the depth of the chl a maximum 
'small flagellate' fraction (cells with diameters $<5 \mu \mathrm{m}$ ) dominated in January and in April after the spring bloom, while dinoflagellates appeared in maximum concentrations during the summer period, June to August (Fig. 4). Chl a concentrations during winter were around $0.1 \mathrm{mg} \mathrm{m}^{-3}$. The average vertical distribution for all stations in the SAF showed highest chl $a$ concentrations in the upper $7.5 \mathrm{~m}$ layer. A maximum chl a concentration of $1.0 \mathrm{mg} \mathrm{m}^{-3}$ was found at a depth of $5 \mathrm{~m}$ (Fig. 3). The phaeopigment concentrations were relatively high, but much lower than the chl a concentrations down to a depth of $10 \mathrm{~m}$. Below a depth of $27 \mathrm{~m}$, the phaeopigment concentrations were higher than the chl a concentrations.

\section{CDOM}

In the coastal waters off SWN in early May, the $a_{\mathrm{y}}(310)$ values of CDOM were within the range 0.7 to $4.7 \mathrm{~m}^{-1}$, with a mean value of $1.88 \mathrm{~m}^{-1}$. The highest values were generally encountered in the surface layer, but also at a depth of $10 \mathrm{~m}$ the CDOM concentrations were high, often approaching the values in the surface layer. At Stn 3 (32 km from the coast) on Transect II, the maximum CDOM concentration was found at a depth of $10 \mathrm{~m}$ (Fig. 5). The overall maximum concentration during the cruise was found at Stn 3 on Transect I, in the middle of the core of NCC water, while on Transects II and III the highest values occurred close to the coast. At a depth of $50 \mathrm{~m}$, below the halocline, the lowest values were found on Transect II. Here, the $a_{\mathrm{y}}(310)$ values of CDOM varied around $1.0 \mathrm{~m}^{-1}$. A relatively high value of $2.0 \mathrm{~m}^{-1}$ at a depth of $50 \mathrm{~m}$ was found close to the coast on Transect III and at Stn 3 on Transect I. On Transect I the highest values at all depths were encountered at Stn 3. Upwelling of saline deep water close to the coast at Stn 1 on Transect I in the SWN (see above) resulted in very low and almost uniformly distributed concentrations of CDOM throughout the water column $\left(a_{\mathrm{y}}(310)\right.$ values were around $\left.1.5 \mathrm{~m}^{-1}\right)$. The $S$ value in SWN waters varied between 0.011 and $0.032 \mathrm{~nm}^{-1}$, and the mean value was $0.0180 \mathrm{~nm}^{-1}\left( \pm 0.0039 \mathrm{~nm}^{-1}\right)$. On Transect II and in the inner part (Stns 1, 2, 3) on Transects I and III, no $S$ values exceeded $0.021 \mathrm{~nm}^{-1}$, indicating that the water masses in the outer parts of Transects I and III were of a different origin compared to the water masses in the inner part.

The $a_{\mathrm{y}}(310)$ values throughout a yearly cycle in the SAF ranged within the interval 0.7 to $7.8 \mathrm{~m}^{-1}$, with the highest values occurring in the surface layer at all stations (Fig. 5). But the CDOM concentrations were larger in the inner part of the fjord. At the 2 outer stations values $>3.5 \mathrm{~m}^{-1}$ were encountered only during

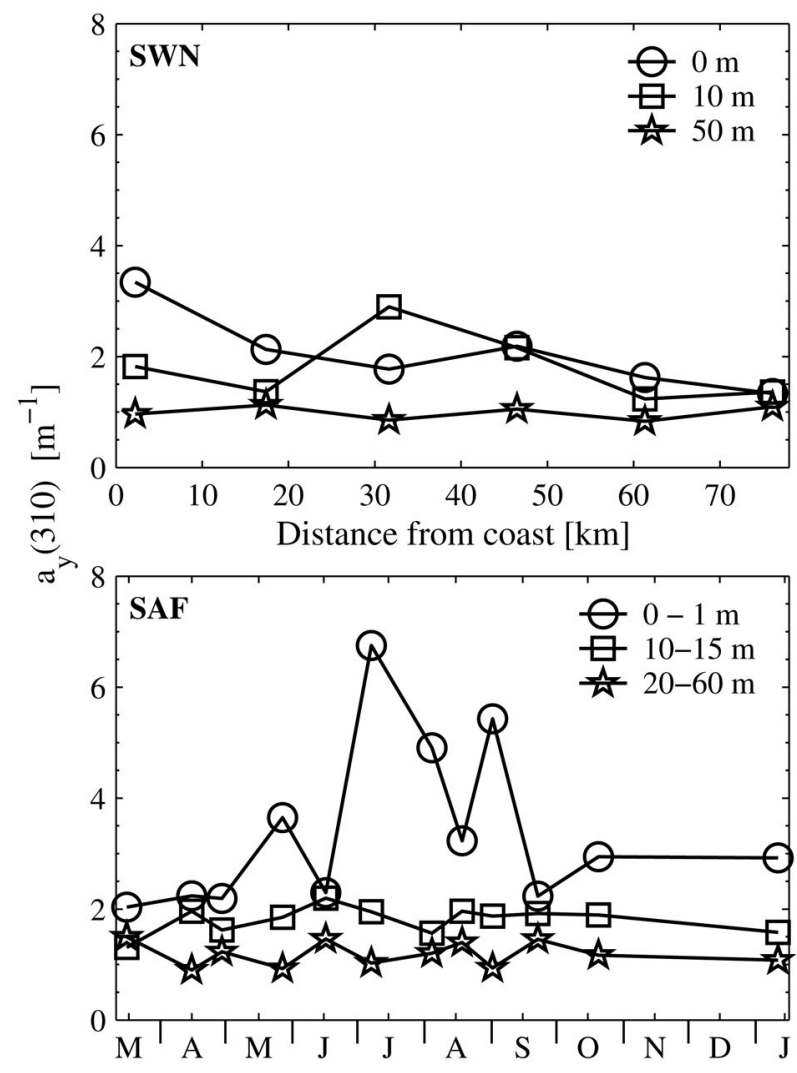

Fig. 5. Variations in the absorption coefficient of coloured dissolved organic matter (CDOM, $\left.a_{y}(310)\right)$ at 3 depth levels in the SWN (Transect II) coastal waters and the SAF (Stn 3) waters

the period early July to early September at Stn 3 (Fig. 5) and in early July at Stn 5 . The $S$ values varied between 0.014 and $0.020 \mathrm{~nm}^{-1}$, and the mean value was $0.017 \mathrm{~nm}^{-1}\left( \pm 0.0015 \mathrm{~nm}^{-1}\right)$, which is close to the mean value found for SWN waters.

\section{UVR and transmission}

Fig. 6 shows UV irradiances just below the surface versus the cosine of the solar zenith angle for a representative number of stations in the waters of the GNS, SWN and SAF. There is a fairly good correlation between measured and CAO-DISORT calculated irradiances at the wavelengths of 305, 320, 340 and $380 \mathrm{~nm}$, taking into account the differences in cloud cover between stations. The sky was mostly cloudy during the GNS cruise, but only results from stations with stable light conditions during the measurement period were included in our data set. In the SAF, UV measurements were carried out in all 4 seasons. Therefore they represent the greatest span both in solar zenith angles during measurement and UV irradiances (Table 3). 


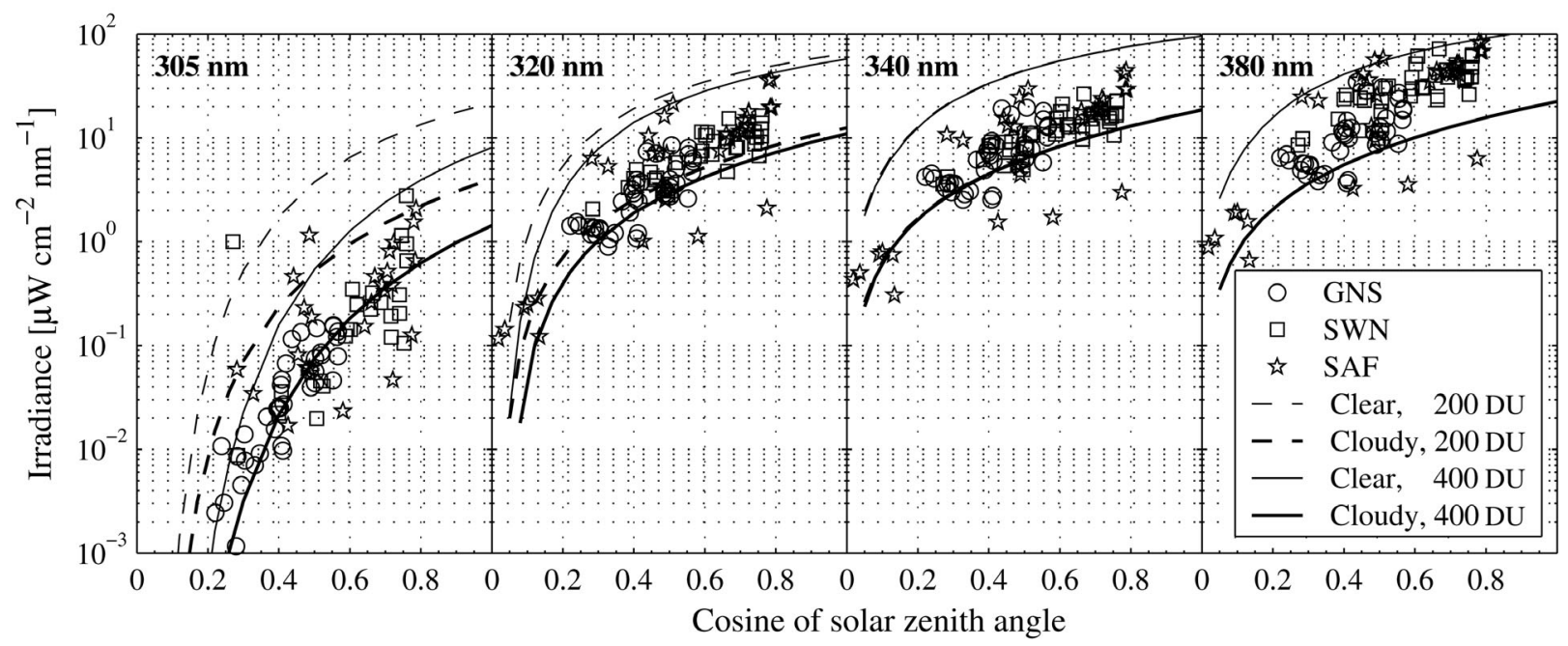

Fig. 6. UV irradiances (just below the surface) versus the cosine of the solar zenith angle at wavelengths of 305, 320, 340 and $380 \mathrm{~nm}$ for the 3 investigation areas GNS-1993, SWN and SAF. The curves were computed with a Coupled Atmosphere-Ocean Discrete-Ordinate Radiative Transfer model. The upper 2 curves represent clear weather conditions with ozone concentrations of 200 and 400 DU, respectively, and the lower 2 curves represent cloudy conditions with ozone concentrations of 200 and $400 \mathrm{DU}$, respectively. At 340 and $380 \mathrm{~nm}$, the 200 and 400 DU curves are indistinguishable. Other model inputs were (1) type of cloud: $1 \mathrm{~km}$ thick Nimbo-Stratus with liquid water content of $0.65 \mathrm{~g} \mathrm{~m}^{-3}$, (2) effective droplet radius $3 \mu \mathrm{m}$, (3) asymmetry factor: $g=0.85$ and (4) subarctic summer atmosphere

Fig. 7 shows the $1 \%$ light depth for the UVR channels at a representative number of stations along the Bear Island-East Greenland transect. The maximum penetration of UVR into the water column was found in the very transparent waters encountered midway along the transect. There the $1 \%$ UVR depths at wavelengths of $305,320,340$ and $380 \mathrm{~nm}$ were found at 10, 22, 34 and $78 \mathrm{~m}$, respectively. Along Transect II in the waters off the SWN, the $1 \%$ UVR depth at 305, 320 and $340 \mathrm{~nm}$ did not change much from the near coast station to Stn 4, which was situated $48 \mathrm{~km}$ offshore. But at $380 \mathrm{~nm}$ the 1\% UVR depth first decreased and then increased along the transect from Stns 2 to 4 . This is probably due to the influence of phytoplankton. The most UVR transparent water on

Table 3. Measured ranges of UV irradiance just below the surface at $305,320,340$ and $380 \mathrm{~nm}$, zenith angle $(\theta)$ and cosine of zenith angle for the 3 investigation areas GNS-1993, SWN and SAF

\begin{tabular}{|lccc|}
\hline $\begin{array}{l}\mathrm{UV} \\
\left(\mu \mathrm{W} \mathrm{cm} \mathrm{cm}^{-2} \mathrm{~nm}^{-1}\right)\end{array}$ & GNS & SWN & SAF \\
\hline $305 \mathrm{~nm}$ & $0.001-0.17$ & $0.009-2.9$ & $0.018-2.0$ \\
$320 \mathrm{~nm}$ & $0.9-8.5$ & $1.5-18.0$ & $0.12-37.0$ \\
$340 \mathrm{~nm}$ & $2.6-18.0$ & $3.5-28.0$ & $0.3-45.0$ \\
$380 \mathrm{~nm}$ & $3.8-32.0$ & $8.5-70.0$ & $0.68-80.0$ \\
$\theta$ & $77.5^{\circ}-54.3^{\circ}$ & $73.8^{\circ}-41.5^{\circ}$ & $88.7^{\circ}-38.0^{\circ}$ \\
$\cos \theta$ & $0.22-0.57$ & $0.28-0.75$ & $0.02-0.79$ \\
\hline
\end{tabular}

the transect was encountered at Stn 5,61 km offshore. There the $1 \%$ UVR depths at 305, 320, 340 and $380 \mathrm{~nm}$ were found at depths of $4.0,5.5,8.0$ and $14.5 \mathrm{~m}$, respectively. In the SAF the $1 \%$ UVR depth was relatively large during spring (March to April), but decreased in May and became relatively shallow during early summer. Maximum 1\% UVR depths were encountered in mid-September, with values at wavelengths of $305,320,340$ and $380 \mathrm{~nm}$ given by $1.3,3.0,4.2$ and $7.5 \mathrm{~m}$, respectively. These increases are due to the main inflow of NCC waters into the SAF at this time (Fig. 2). In October the $1 \%$ UVR depths at 305, 320, 340 and $380 \mathrm{~nm}$ were found to be $0.7,1.5,2.2$ and $3.5 \mathrm{~m}$, respectively, and they remained at these values during the winter season. From the data presented above it follows that the maximum $1 \%$ UVR depth gradually decreased when passing from oceanic via coastal to fjord water.

\section{Primary production}

In the $\mathrm{SAF}$ a maximum ${ }^{14} \mathrm{C}$-assimilation rate of 12.4 $\mathrm{mg} \mathrm{C} \mathrm{m}^{-3} \mathrm{~h}^{-1}$ was observed close to the surface on 17 March. Typical for the rest of the productive season were values within the range of 1.0 to $3.4 \mathrm{mg} \mathrm{C} \mathrm{m}^{-3} \mathrm{~h}^{-1}$, and these were restricted to the upper $2 \mathrm{~m}$ layer of the water column. Relatively high subsurface values of 5.3 and $1.3 \mathrm{mg} \mathrm{C} \mathrm{m}^{-3} \mathrm{~h}^{-1}$ at a depth of $7.5 \mathrm{~m}$ were encountered on 15 April and 18 August, respectively. 
In January, light intensities were too low to achieve net photosynthesis. The vertically integrated in situ primary production and production efficiencies were at maximum during the spring bloom, when $34 \mathrm{mg} \mathrm{C}$ $\mathrm{mg}^{-1}$ chl a d $\mathrm{d}^{-1}$ (Table 4) was obtained on 17 March, while the mean value of production efficiencies for the productive layer during the period April to October was $17.5 \mathrm{mg} \mathrm{C} \mathrm{mg}^{-1} \mathrm{chl} \mathrm{a} \mathrm{d} \mathrm{d}^{-1}$. The total integrated primary production in the SAF during the period March to October was measured at $112 \mathrm{~g} \mathrm{C} \mathrm{m}^{-2}$. The primary production yields for the SAF compare well with those
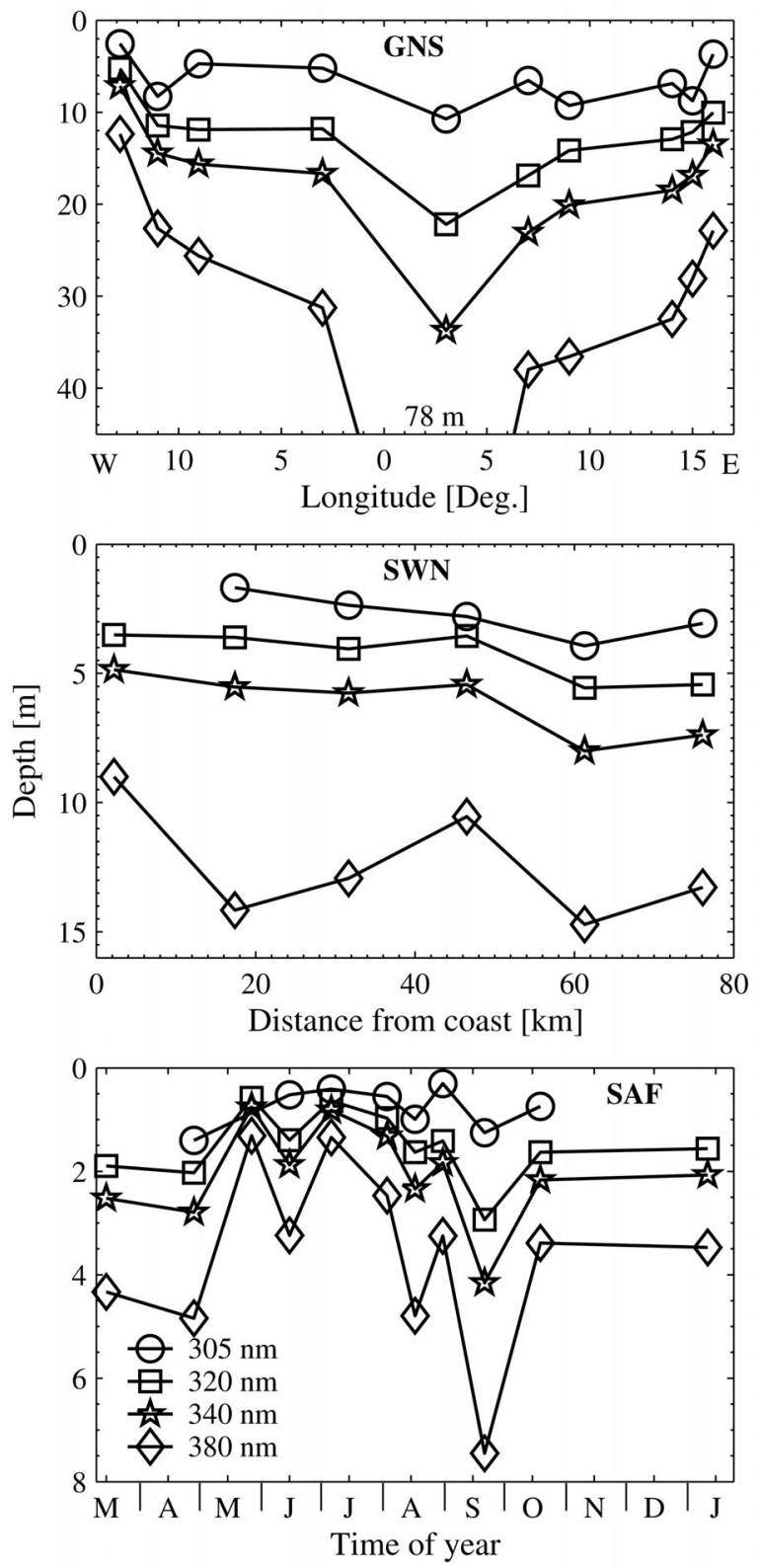

Fig. 7. Variations in the $1 \%$ UVR depth at $305,320,340$ and $380 \mathrm{~nm}$ in the 3 investigation areas GNS-1993 (transect Bear Island-East Greenland), SWN (Transect II) and SAF (Stn 3). Note the different depth scales from 2 other western Norwegian fjords (Erga \& Heimdal 1984, Erga 1989b). In the GNS, typical mean ${ }^{14} \mathrm{C}$ assimilation rates above, in and below the pycnocline (situated around $30 \mathrm{~m}$ ) were 8.9, 6.3 and $1.6 \mathrm{mg} \mathrm{C} \mathrm{m}^{-3}$ $\mathrm{h}^{-1}$, respectively.

Fig. 8a,c shows primary production calculations based upon ${ }^{14} \mathrm{C}$-uptake values versus those based on natural fluorescence values for the SAF and GNS, respectively. It can be seen that the degree of conformity between these 2 ways of calculating primary production was relatively good, both for the SAF and GNS, but that a better correlation between them was obtained for the clear oceanic waters of the GNS. Fig. 8b shows primary production calculations based on ${ }^{14} \mathrm{C}$-uptake versus those based on values predicted from measured PAR and UVR levels for the SAF, which are seen to be in good accordance with that shown in Fig. 8a for ${ }^{14} \mathrm{C}$-uptake versus natural fluorescence. It should be noted that ${ }^{14} \mathrm{C}$-uptake measurements at discrete depths were based on $24 \mathrm{~h}$ in situ incubations (i.e. net photosynthesis) at Stn 3 in the SAF, and upon $2 \mathrm{~h}$ incubations on-deck in the GNS, whereas the natural fluorescence and PAR/UVR values were obtained from single measurements at the time of sampling at the same discrete depths as for the ${ }^{14} \mathrm{C}$-uptake measurements.

It should be kept in mind that the upper $5 \mathrm{~m}$ of the water column was not included in the primary production calculations based on natural fluorescence, due to influences of natural backscattered red light close to the surface (Maritorena et al. 2000, Morrison 2003) (see 'Discussion' for further details). The effect of excluding the upper $5 \mathrm{~m}$ layer is probably largest in strongly stratified waters like those in the SAF, where high surface concentrations of CDOM during summer

Table 4. Daily integrals of carbon assimilation $(P)$ within the depth intervals 0 to 20 and 5 to $20 \mathrm{~m}$, and integrated $P / B$ ratios (daily integrals of carbon assimilation over chl a $[B]$, both integrated over the upper $20 \mathrm{~m}$ ) at Stn 3 in the SAF during the period 17 March 1999 to 11 January 2000

\begin{tabular}{|cccc|}
\hline \multicolumn{2}{|c|}{$\begin{array}{c}P(0-20 \mathrm{~m}) \\
\left(\mathrm{mg} \mathrm{C} \mathrm{m}^{-2} \mathrm{~d}^{-1}\right)\end{array}$} & $\begin{array}{c}P(5-20 \mathrm{~m}) \\
\left(\mathrm{mg} \mathrm{C} \mathrm{m}^{-2} \mathrm{~d}^{-1}\right)\end{array}$ & $\begin{array}{c}P / B(0-20 \mathrm{~m}) \\
\left(\mathrm{mg} \mathrm{C} \mathrm{m}^{-1} \mathrm{chl} \mathrm{a} \mathrm{d}^{-1}\right)\end{array}$ \\
\hline 17 Mar & 1254 & 405 & 34.1 \\
15 Apr & 412 & 244 & 15.5 \\
29 Apr & 305 & 115 & 26.5 \\
27 May & 294 & 149 & 16.7 \\
17 Jun & 451 & 182 & 12.7 \\
7 Jul & 497 & 234 & 23.8 \\
4 Aug & 302 & 179 & 11.2 \\
18 Aug & 459 & 309 & 17.5 \\
1 Sep & 133 & 43 & 7.5 \\
22 Sep & 325 & 81 & 21.9 \\
20 Oct & 114 & 22 & 1.0 \\
11 Jan & 1.5 & 0 & \\
\end{tabular}



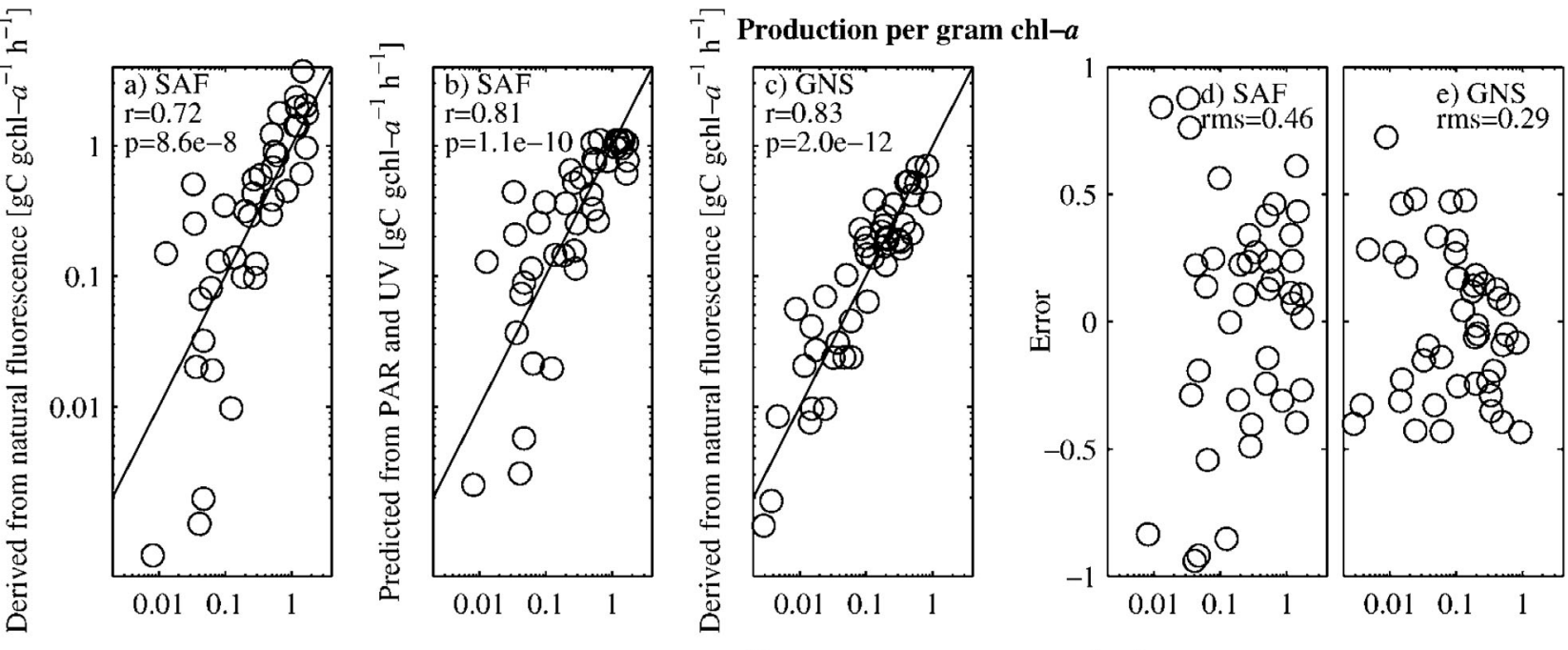

Derived from ${ }^{14} \mathrm{C}$ incubation [gC gchl- $a^{-1} \mathrm{~h}^{-1}$ ]

Fig. 8. Comparisons of primary production in fjord waters (SAF) and oceanic waters (GNS), estimated from ${ }^{14} \mathrm{C}$-incubations $\left(P_{14 \mathrm{C}}\right)$, natural fluorescence $\left(P_{\text {fluo }}\right)$ and PAR + UV irradiances. (a) Correlation between hourly production based on $24 \mathrm{~h}$ in situ $P_{14 \mathrm{C}}$ and $P_{\text {fluo }}$ in the SAF. (b) Correlation between hourly production based on $24 \mathrm{~h}$ in situ $P_{14 \mathrm{C}}$ and model prediction of primary production based on PAR + UV irradiances in the SAF. (c) Correlation between hourly production based on $2 \mathrm{~h}$ on-deck $P_{14 \mathrm{C}}$ and $P_{\text {fluo }}$ in the GNS. The relative error between primary production derived from natural fluorescence and ${ }^{14} \mathrm{C}$-incubations in the SAF (d) and GNS (e). The error was calculated as $\left(P_{\text {fluo }}-P_{14 \mathrm{C}}\right) /\left(P_{\text {fluo }}+P_{14 \mathrm{C}}\right)$, which means that when the error is, e.g., 0.33 then $P_{\text {fluo }}$ is twice as large as $P_{14 \mathrm{C}}$ and when the error is -0.33 then $P_{\text {fluo }}$ is half the value of $P_{14 \mathrm{C}}$ (rms: root mean square). It should be noted that the constant $\left(\varphi_{\mathrm{c}} / \varphi_{\mathrm{f}}\right)_{\max }$ in (a) and (c) and the constant $P_{\mathrm{s}}^{\mathrm{B}}\left(\mathrm{g} \mathrm{C} \mathrm{g}^{-1} \mathrm{chl} \mathrm{a} \mathrm{h}{ }^{-1}\right)$ in (b) were chosen so that the slope of the regression is equal to 1

will decrease the UVR penetration, which in turn will tend to increase the productivity of phytoplankton cells in the upper layer. For cases in which relatively high concentrations of inorganic particles accompany high CDOM levels, this effect may be reduced due to scattering of UVR. Note that since the 3 study areas were sampled in different years, our comparisons of primary production in the different areas may have been influenced by possible variations from one year to another in the parameters used in the primary production calculations.

Fig. 9a-c shows that the depth distribution of photosynthetic activity falls into 3 categories, in accordance with the 3 main water types covered by our sampling programme. The depth down to which high photosynthetic rates were encountered decreases successively from the oceanic water of the GNS via the coastal water of the SWN to the fjord water of the SAF. But vertical profiles at the 9 stations covering the western part of the GNS (Stns 657 to 671) show lower production (Fig. 9a) and production per gram chl a (Fig. 9j) than at the stations in the Norwegian Sea. This is probably due to more extensive nitrate limitation in the Greenland Sea than in the Norwegian Sea (Rey et al. 2000) at the time of investigation. These phytoplankton populations probably originated in more nutrient-rich areas farther north and were brought to the Greenland Sea by the East Greenland Current.
In May relatively high photosynthetic rates were encountered at larger depths in the coastal waters of the SWN than in the fjord waters of the SAF, but the maximum values were lower in SWN waters (Fig. 9c). The lower photosynthetic rates at the inner parts on Transect III were accompanied by relatively higher chl a concentrations (Fig. 9r), resulting in low production efficiencies (Fig. 91). Due to a general tendency of low chl a concentrations in SWN waters, however, high photosynthetic efficiencies were encountered deeper than $20 \mathrm{~m}$ in these waters (Fig. 9i,l). When considering the photosynthetic efficiency of the upper $30 \mathrm{~m}$ of the water column, it appears that it is higher in SWN waters than in SAF waters.

With few exceptions the highest photosynthetic rates and production efficiencies derived from natural fluorescence in the SAF were encountered during the summer season May to August (Fig. 9b,k). However, on 17 March these values were significantly lower than the values obtained from ${ }^{14} \mathrm{C}$-uptake measurements. These discrepancies may be due to variable weather conditions on 17 March, with fog and rain in the morning at the time of light and natural fluorescence measurements (see Fig. 9n). Later in the day, weather conditions improved. Also, due to suboptimal light conditions on this date, a relatively high percentage of the measured ${ }^{14} \mathrm{C}$-uptake may have occurred in the upper $5 \mathrm{~m}$ of the water column (Table 4), where natural fluorescence was not measured, for reasons explained earlier. 
GNS
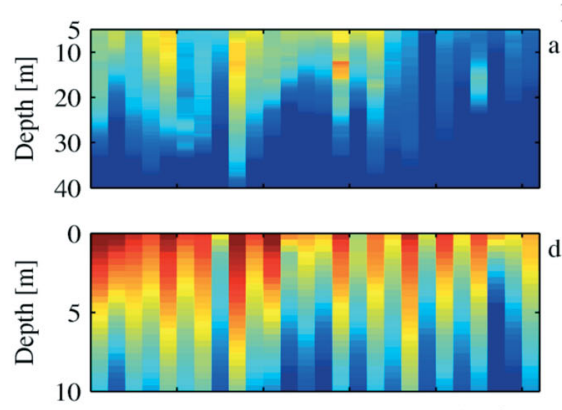

SAF

Production derived from fluorescence $\left[\mathrm{mgC} \mathrm{m}^{-3} \mathrm{~h}^{-1}\right.$

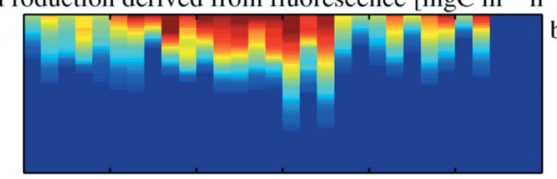

Inhibition estimated from measured UV

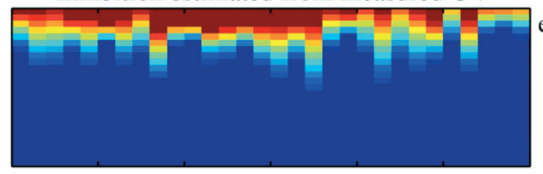

SWN
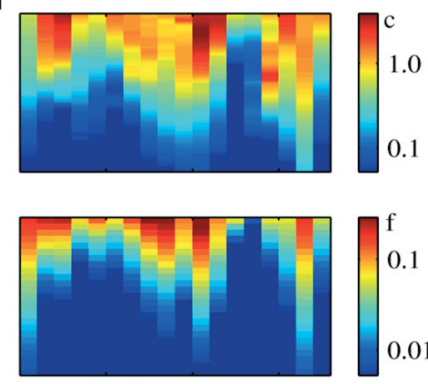
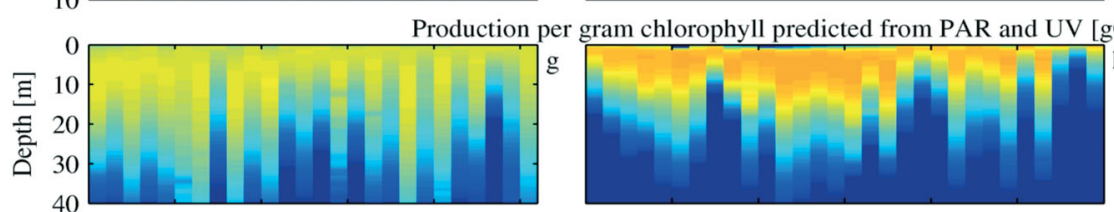

$\left.\operatorname{gchl}-a^{-1} \mathrm{~h}^{-1}\right]$

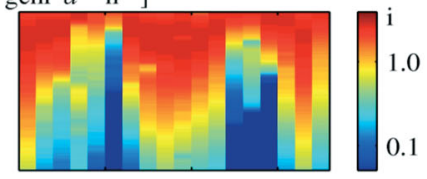

Production per gram chlorophyll derived from fluorescence $\left[\mathrm{gC} \mathrm{gchl}-a^{-1} \mathrm{~h}^{-1}\right.$ ]
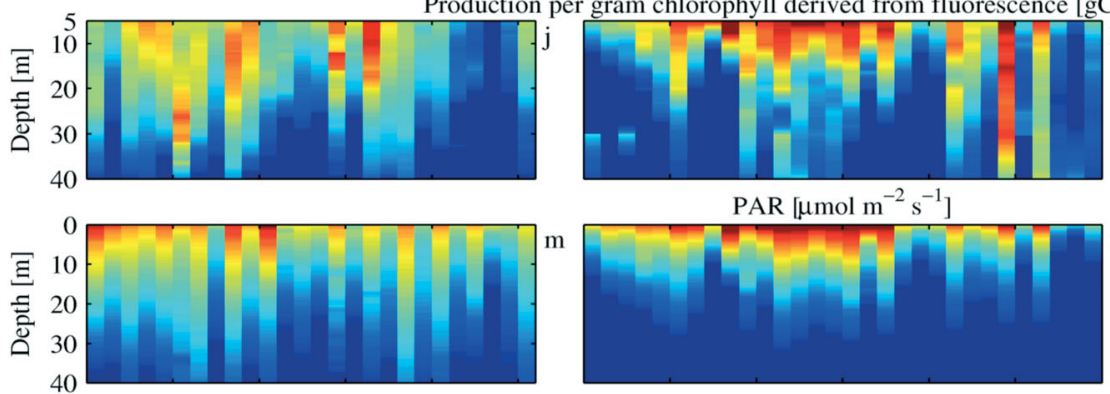

PAR $\left[\mu \mathrm{mol} \mathrm{m}^{-2} \mathrm{~s}^{-1}\right]$
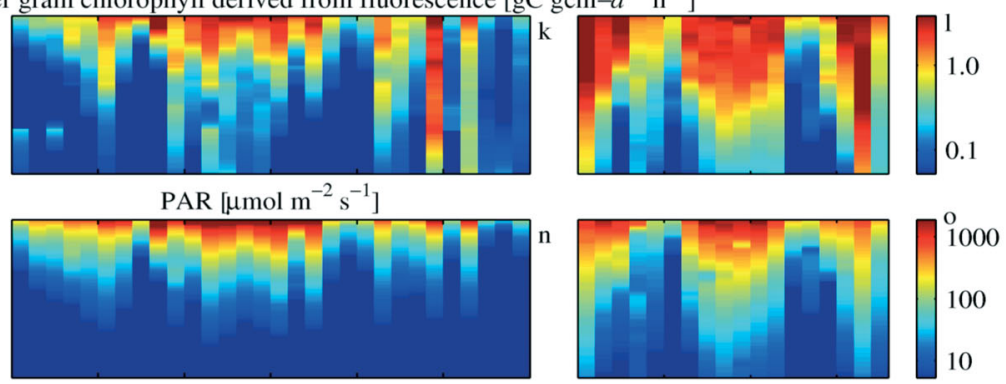

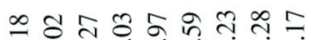

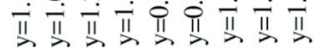

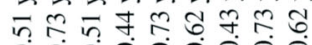
îj

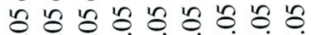

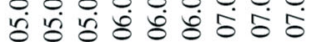

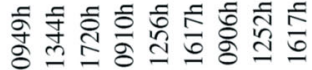

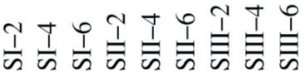

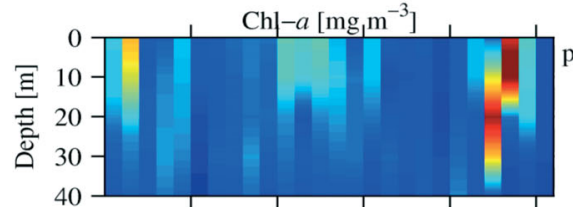

શ

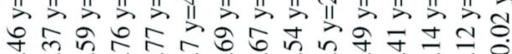
이잉

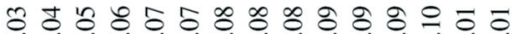
ป 웡 籿守 $n \bar{n} \bar{n} \tilde{n} \tilde{n} \bar{n} \tilde{n} \bar{n} \tilde{n} \bar{n} \tilde{n}$
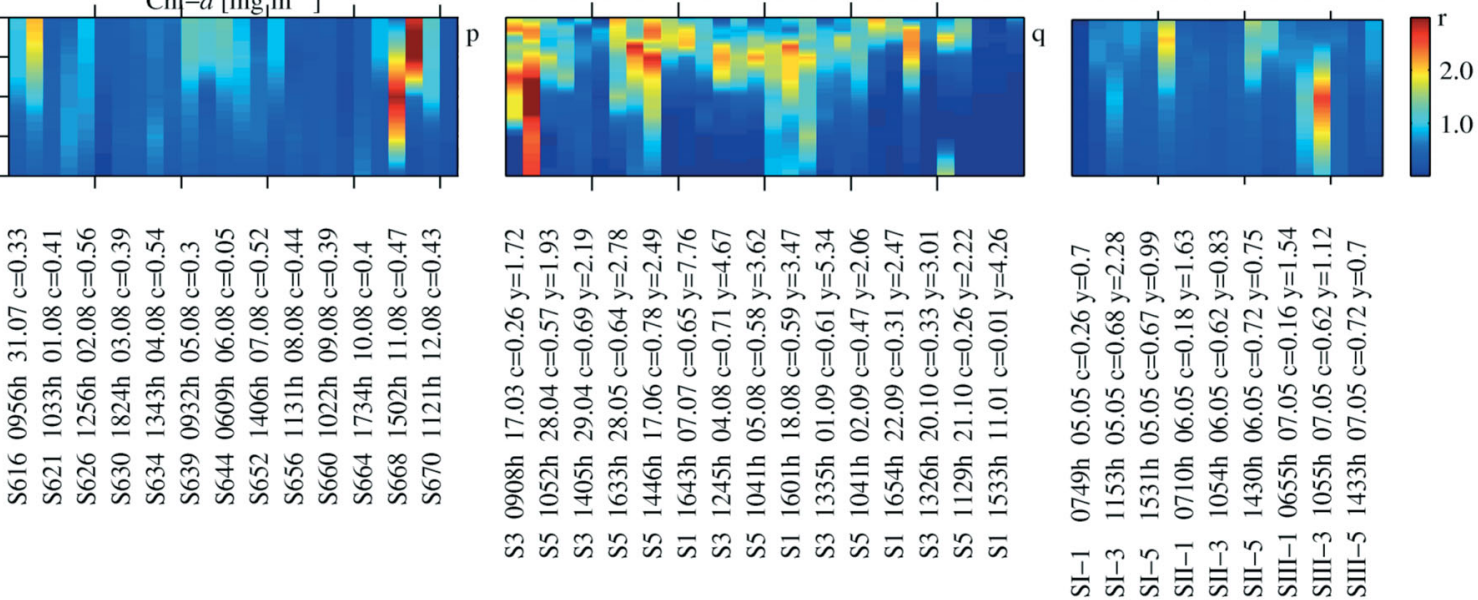

Fig. 9. Depth distributions of $(a, b, c)$ primary production derived from natural fluorescence, $(d, e, f)$ potential for inhibition due to UVR and PAR (relative scale), $(\mathrm{g}, \mathrm{h}, \mathrm{i})$ primary production per gram chl a predicted from PAR and UVR, $(\mathrm{j}, \mathrm{k}, \mathrm{l})$ primary production per gram chl a derived from natural fluorescence, $(m, n, o)$ PAR and $(p, q, r)$ chl a for the 3 investigation areas GNS-1993, SWN and SAF. In (p), (q) and (r), information on sampling time, date, cosine of the solar zenith angle at sampling (c) and the maximum concentration of $\operatorname{CDOM}(y)$ at each station is indicated alternately above and below the columns 


\section{DISCUSSION}

\section{Impact of CDOM and chl $a$ on UVR transmission}

Just below the surface in the GNS our downward UVR irradiances were lower than those reported by Vasseur et al. (2003) as averages for northern Baffin Bay (eastern Canada). These authors emphasised the fact that their measurements were conducted during variable weather conditions. Our values (Table 3) are more in agreement with their September recordings. The values of Vasseur et al. (2003) ranged between 0.03 and $0.27 \mu \mathrm{W} \mathrm{cm}^{-2} \mathrm{~nm}^{-1}$ at $305 \mathrm{~nm}$, between 1.70

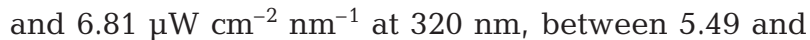
$17.95 \mu \mathrm{W} \mathrm{cm} \mathrm{cm}^{-2} \mathrm{~nm}^{-1}$ at $340 \mathrm{~nm}$ and between 7.86 and $25.58 \mu \mathrm{W} \mathrm{cm}{ }^{-2} \mathrm{~nm}^{-1}$ at $380 \mathrm{~nm}$. Sampling times were at different times of the day, thus representing variable light conditions during the day. Compared with the investigation in Baffin Bay, our sampling area was situated some degrees farther south $\left(72^{\circ} 30^{\prime} \mathrm{N}\right.$ to $\left.76^{\circ} 01^{\prime} \mathrm{N}\right)$.

Fig. 10 shows the impact of chl $a$ on the diffuse attenuation coefficient $\left(K_{\mathrm{d}}\right)$ for UV irradiance in our 3 investigation areas. These results are in relatively good agreement with those published for Baffin Bay. During periods with very low concentrations of CDOM and particles, Højerslev \& Aas (1991) found even more transparent water in the Norwegian Sea, indicated by $K_{\mathrm{d}}(310 \mathrm{~nm})$ values in the range of 0.15 to $0.20 \mathrm{~m}^{-1}$. The correlations between the diffuse attenuation coefficient and the chl a concentration in the GNS were good, except at the wavelength of $305 \mathrm{~nm}$ (Table 5). The low correlation at $305 \mathrm{~nm}$ may be explained by the fact that in some cases the turbidity may have been so high or the light intensity so low that the $K_{\mathrm{d}}(305)$ could not be estimated accurately due to signal strengths close to noise level within the $305 \mathrm{~nm}$ band. When this happen $K_{\mathrm{d}}(305)$ could erroneously be found to be lower than $K_{\mathrm{d}}(320)$. Such values were rejected, leading to fewer entries at $305 \mathrm{~nm}$ in Table 5. By considering only stations in the GNS with typically low chl a concentrations ( 0.3 to $0.4 \mathrm{mg} \mathrm{m}^{-3}$ ), we find the diffuse attenuation coefficients at $305,320,340$ and $380 \mathrm{~nm}$ to be comparable to those in waters classified by Jerlov (1976) as Oceanic II. Our values are also close to those given by Piazena et al. (2002) for central subtropical Atlantic waters around the Azores. They emphasised that those parts of the water masses investigated, which can be characterised as Oceanic II waters, typically had $1 \%$ UVR depths for wavelengths of 305,320 , 340 and $380 \mathrm{~nm}$ around 10, 20, 35 and 50 to $70 \mathrm{~m}$, respectively. These values are in close agreement with our maximum values for the GNS. In an investigation in the Greenland Sea and the northern part of the Barents Sea, Aas \& Høkedal (1996) found the average $1 \%$ UVR depth at $306 \mathrm{~nm}$ to be around $10 \mathrm{~m}$.

According to Dring et al. (2001), the marine waters around Helgoland in the southern North Sea are among those having the strongest UVR attenuation. They reported mean diffuse attenuation coefficients during the summer months at 305 and $320 \mathrm{~nm}$ of 3.5 and $2.5 \mathrm{~m}^{-1}$, respectively. Our measurements in SWN waters gave $K_{\mathrm{d}}(305)$ values between 0.6 and $4 \mathrm{~m}^{-1}$ and $K_{\mathrm{d}}(320)$ values between 0.55 and $2.8 \mathrm{~m}^{-1}$ (Fig. 10). These values compare well with the mean value of $2.7 \mathrm{~m}^{-1}$ reported for $K_{\mathrm{d}}(310)$ in the Kattegat (Aas \& Højerslev 2001). In the SAF the $K_{\mathrm{d}}$ values at 305 and $320 \mathrm{~nm}$ ranged between 4 and $>9 \mathrm{~m}^{-1}$ (the latter could not be determined accurately due to very low signals) and between 1.5 and $9 \mathrm{~m}^{-1}$, respectively, which are

Table 5. Correlation data for the diffuse attenuation coefficient $\left(K_{\mathrm{d}}\right)$ versus $\operatorname{chl} a(C)$, and CDOM $(Y)$ measured as $a_{\mathrm{y}}(310)$, at UV 305, 320, 340 and $380 \mathrm{~nm}$ for the 3 investigation areas GNS-1993, SAF and SWN. $A$ and $B$ are coefficients, and W indicates pure water

\begin{tabular}{|c|c|c|c|c|c|c|c|c|c|c|c|}
\hline \multirow[t]{2}{*}{ Area } & \multirow{2}{*}{$\begin{array}{l}\text { Wave- } \\
\text { length } \\
(\mathrm{nm})\end{array}$} & \multicolumn{5}{|c|}{$K_{C}=K_{\mathrm{W}}+A \times C^{B}$} & \multicolumn{5}{|c|}{$K_{Y}=K_{\mathrm{W}}+A \times Y^{B}$} \\
\hline & & $A$ & $B$ & $\mathrm{r}$ & $\mathrm{p}$ & $\mathrm{N}$ & $A$ & $B$ & $\mathrm{r}$ & $\mathrm{p}$ & $\mathrm{N}$ \\
\hline GNS & $\begin{array}{l}305 \\
320 \\
340 \\
380\end{array}$ & $\begin{array}{l}0.60 \\
0.34 \\
0.26 \\
0.16\end{array}$ & $\begin{array}{l}0.39 \\
0.51 \\
0.55 \\
0.57\end{array}$ & $\begin{array}{l}0.55 \\
0.82 \\
0.81 \\
0.78\end{array}$ & $\begin{array}{l}4.80 \times 10^{-04} \\
2.50 \times 10^{-10} \\
3.20 \times 10^{-10} \\
5.70 \times 10^{-09}\end{array}$ & $\begin{array}{l}37 \\
39 \\
39 \\
39\end{array}$ & & & & & \\
\hline SAF & $\begin{array}{l}305 \\
320 \\
340 \\
380\end{array}$ & $\begin{array}{l}6.11 \\
3.09 \\
2.28 \\
1.32\end{array}$ & $\begin{array}{l}-0.22 \\
-0.15 \\
-0.16 \\
-0.16\end{array}$ & $\begin{array}{l}-0.31 \\
-0.29 \\
-0.31 \\
-0.30\end{array}$ & $\begin{array}{l}1.30 \times 10^{-01} \\
9.70 \times 10^{-02} \\
8.40 \times 10^{-02} \\
8.50 \times 10^{-02}\end{array}$ & $\begin{array}{l}25 \\
33 \\
33 \\
33\end{array}$ & $\begin{array}{l}2.26 \\
0.72 \\
0.52 \\
0.30\end{array}$ & $\begin{array}{l}0.86 \\
1.24 \\
1.27 \\
1.27\end{array}$ & $\begin{array}{l}0.77 \\
0.94 \\
0.94 \\
0.92\end{array}$ & $\begin{array}{l}5.20 \times 10^{-06} \\
6.30 \times 10^{-17} \\
1.60 \times 10^{-16} \\
2.90 \times 10^{-14}\end{array}$ & $\begin{array}{l}26 \\
34 \\
34 \\
34\end{array}$ \\
\hline SWN & $\begin{array}{l}305 \\
320 \\
340 \\
380\end{array}$ & $\begin{array}{l}1.70 \\
1.25 \\
0.91 \\
0.52\end{array}$ & $\begin{array}{l}0.13 \\
0.05 \\
0.05 \\
0.08\end{array}$ & $\begin{array}{l}0.26 \\
0.10 \\
0.11 \\
0.17\end{array}$ & $\begin{array}{l}2.20 \times 10^{-01} \\
5.50 \times 10^{-01} \\
5.10 \times 10^{-01} \\
3.20 \times 10^{-01}\end{array}$ & $\begin{array}{l}24 \\
38 \\
38 \\
38\end{array}$ & $\begin{array}{l}0.87 \\
0.65 \\
0.47 \\
0.27\end{array}$ & $\begin{array}{l}0.68 \\
0.65 \\
0.65 \\
0.63\end{array}$ & $\begin{array}{l}0.49 \\
0.60 \\
0.61 \\
0.61\end{array}$ & $\begin{array}{l}1.50 \times 10^{-02} \\
7.20 \times 10^{-05} \\
4.10 \times 10^{-05} \\
4.40 \times 10^{-05}\end{array}$ & $\begin{array}{l}24 \\
38 \\
38 \\
38\end{array}$ \\
\hline
\end{tabular}




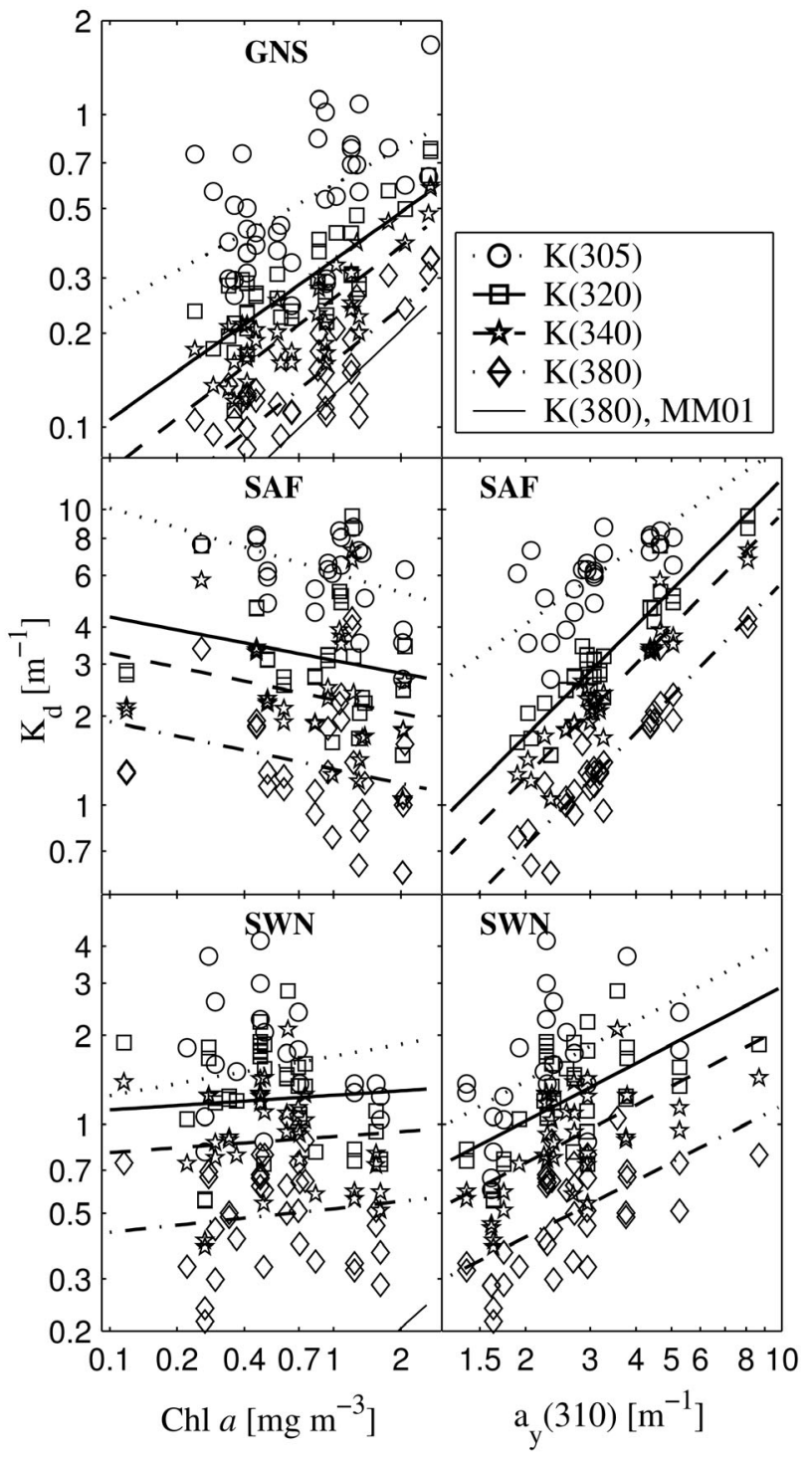

Fig. 10. Diffuse attenuation coefficient $\left(K_{\mathrm{d}}\right)$ versus chl $a$ and $\operatorname{CDOM}\left(a_{\mathrm{y}}(310)\right)$ concentrations at $305,320,340$ and $380 \mathrm{~nm}$ at the 3 investigation areas GNS-1993, SAF and SWN. The curve denoted ' $K(380)$, MM01' was adapted from the parameterisation of $K_{\mathrm{d}}$ at $380 \mathrm{~nm}$ given in Morel \& Maritorena (2001). Data for the fitted curves are given in Table 5

considerably higher than the corresponding values found in SWN waters. Also the UV-A radiation was more strongly attenuated in SAF waters than at Helgoland.

CDOM levels measured as $a_{\mathrm{y}}(310)$ in SAF and SWN waters were the same at depths $>10 \mathrm{~m}$, with values mostly $<2 \mathrm{~m}^{-1}$ (Fig. 5). However, high surface values were encountered in the SAF during the period July to September. In May the surface value of CDOM in the SAF was $3.5 \mathrm{~m}^{-1}$, the same as at the near-shore station on Transect II in SWN waters. The mean value for the CDOM attenuation in SWN waters was $1.88 \mathrm{~m}^{-1}$. In earlier comprehensive investigations during spring and summer in the Kattegat-Skagerrak area, CDOM concentrations (measured as $a_{\mathrm{y}} 310$ ) were found to vary from 0.06 to $7.4 \mathrm{~m}^{-1}$ in open coastal waters, with a mean value of $1.3 \mathrm{~m}^{-1}$ (Højerslev \& Aas 2001). They reported the maximum and mean values of the wavelength-averaged slope $S$ to be, respectively, 0.042 and $0.022 \mathrm{~nm}^{-1}$. These values are somewhat higher than our maximum and mean values for SWN waters (0.032 and $0.018 \mathrm{~nm}^{-1}$ ) and SAF waters (0.020 and $0.017 \mathrm{~nm}^{-1}$ ). According to Green \& Blough (1994), $S$ values $>0.030 \mathrm{~nm}^{-1}$ indicate water of oceanic origin, while $S$ values around $0.014 \mathrm{~nm}^{-1}$ indicate terrestrial influence. Frette et al. (2004) concluded that the main source of CDOM in the SAF was river outlets. It has also been shown that high $S$ values may arise due to high doses of solar irradiance, which increase the photo-mineralisation of dissolved organic matter (Obernosterer \& Benner 2004). Thus, high $S$ values may be typical for older water masses. The relatively close co-variation of CDOM and mean $S$ values between fjord and coastal waters in our study, supports the view of Frette et al. (2004) that the phytoplankton bloom dynamics in the SAF is strongly interrelated with that in adjacent NCC waters.

From our data it is clear that CDOM measured as $a_{y}(310)$ was the main contributor to the attenuation of UV radiation in the SAF (Fig. 10, Table 5). Also, CDOM was the most important contributor to the absorption at $412 \mathrm{~nm}$. Since the $S$ values in the SAF did not change significantly between stations or with depth (mean = $0.017 \pm 0.0015 \mathrm{~nm}^{-1}$ ), we expect to find a similar degree of conformity between respectively $K_{\mathrm{d}}(305), K_{\mathrm{d}}(320)$, $K_{\mathrm{d}}(340), K_{\mathrm{d}}(380)$, and $\operatorname{CDOM}(305), \operatorname{CDOM}(320)$, $\operatorname{CDOM}(340), \operatorname{CDOM}(380)$. In the coastal waters of the SWN, CDOM was more important than chl a for UVR attenuation (Fig. 10). But the correlations between CDOM and $K_{\mathrm{d}}$ were weaker than in the SAF. In SAF waters $\mathrm{r}$ values varied between 0.77 and 0.94 , and $\mathrm{p}<0.000005$, whereas in SWN waters $\mathrm{r}$ values were in the range of 0.49 to 0.61 , and $p<0.02$ (Table 5). This difference between SAF and SWN waters is to be expected due to higher CDOM concentrations in the upper layer of the SAF during summer (Fig. 5). The UVR attenuation in SWN waters compares well with the yearly average found in the coastal waters of Japan (Kuwahara et al. 2000). Note also that UVR attenuation in the coastal waters of the SWN in May was close to the yearly minimum value found in SAF waters (Fig. 10), and close also to mean values presented by Dring et al. (2001) for the summer period in Helgoland waters. Since the absorption coefficient of CDOM at $440 \mathrm{~nm}$ co-varies with chl $a$, and since there is an exponential decrease of CDOM absorption with wavelength (Morel \& Maritorena 2001), we expect that 
CDOM will contribute to the attenuation of UV-B radiation in the GNS. The maximum UVR transmission observed in the fjord water of the SAF was only $10 \%$ of that found in the oceanic water of the GNS.

From the similarities in optical properties between the geographically separated water masses found in the southern North Sea, Skagerrak-Kattegat, NCC waters of the SWN and SAF waters, we conclude that there is a continuous change in water type as one moves from one geographical area to another. This kind of continuity can be explained by the well-known advection pattern for these waters (Aure et al. 1998). In accordance with this, waters from the southern North Sea are connected with SWN waters, both by the NCC and the Jutland Current along the west coast of Denmark. In the beginning the NCC also recruits waters from the Kattegat. Our data show that on its way along the SWN coast NCC waters are to a certain degree influenced by admixture from adjacent water masses. The influence from brackish Kattegat water and/or land run-off can be recognised on Transect III by salinities $<25$ in the upper $5 \mathrm{~m}$ layer and maximum CDOM concentrations at the inner station, where $a_{\mathrm{y}}(310)=2.0 \mathrm{~m}^{-1}$ at $50 \mathrm{~m}$ and $a_{\mathrm{y}}(310)=3.5 \mathrm{~m}^{-1}$ at 10 and $0 \mathrm{~m}$. At this position the core of the NCC was close to the coast. Farther to the north, on Transect II, the brackish core of the NCC was forced offshore (Fig. 2), leading to a high concentration of $\operatorname{CDOM}\left(a_{\mathrm{y}}(310)=2.8 \mathrm{~m}^{-1}\right)$ at a depth of $10 \mathrm{~m}, 30 \mathrm{~km}$ from the coast. Nonetheless CDOM concentrations were high at the surface close to the coast (Fig. 5). The outer station, however, was more haline (Fig. 2) and less influenced by CDOM (Fig. 5), due to a higher contribution of less turbid North Sea water than at the stations closer to the coast. After passing the extensive fjord systems of the SWN (see Fig. 1), the NCC probably receives waters from the fjords by wind-driven exchange processes (Sætre et al. 1988, Erga 1989a). In the SAF a pattern of decreasing CDOM concentrations with increasing salinity was found (Frette et al. 2004). This is also a general trend in North European coastal waters (Aas and Højerslev 2001), which is confirmed by our data from SWN waters. In some cases, however, the CDOM concentration does not seem to decrease as the salinity increases, probably due to different sources of riverine inputs (Aas \& Højerslev 2001). Also, the optical properties of CDOM may change with time due to photo-mineralisation and photo-transformations (Obernosterer \& Benner 2004). With respect to tracking of water masses in coastal and fjord areas, CDOM and salinity variation patterns seem to complement one another. Temperature variation patterns are, on the other hand, far less informative due to their low importance for seawater density in coastal and fjord waters.

To characterise the optical properties of marine waters in the absence of $\mathrm{chl} a$, the background level of particulate organic carbon (POC) is an important parameter, because this is what we consider to be a body of 'zero' phytoplankton biomass water, i.e. clear deep water or low biomass winter water in general. It can be obtained from linear relationships between chl $a$ and POC (Table 6). Common to the waters of the SAF and the Bokna fjord, which constitutes the fjord system just north of Transect I, are POC background levels within the range of 47 to $52 \mathrm{mg} \mathrm{m}^{-3}$, which represent about $10 \%$ of the POC concentrations during moderate phytoplankton blooms. These POC background levels compare fairly well with the POC concentration (40 mg $\mathrm{m}^{-3}$ ) encountered at a depth of $100 \mathrm{~m}$ in November in the Bokna fjord (authors' unpubl. data).

\section{Effects of UVR transmission on primary production and vertical distribution of phytoplankton}

The estimates of primary production are based on measurements of both natural fluorescence and ${ }^{14} \mathrm{C}$ uptake in all investigation areas. But the relationship between natural fluorescence and primary production is quite complicated (Garcia-Mendoza \& Maske 1996, Westberry \& Siegel 2003, Yoshikawa \& Furuya 2004). It depends on the daylight irradiance, the degree of phytoplankton light acclimation and adaptation, nutrient concentrations, temperature and probably other regulating factors. These parameters are important governing factors for the physiological condition of the phytoplankton. The influence of available scalar PAR irradiance and temperature on the primary production obtained from natural fluorescence is taken into account in Eq. (2). In addition, the measured signal in the fluorescence band may contain contributions from backscattered and Raman scattered light. According to Westberry \& Siegel (2003) the fraction of $L_{\mathrm{u}}(683, z)$ due to Raman scattering is less than about $8 \%$ of the measured signal when chl a values are $>0.1 \mathrm{mg} \mathrm{m}^{-3}$. In most of our measurements we had chl a values that were $>0.1 \mathrm{mg} \mathrm{m}^{-3}$. Therefore, we neglect effects due to Raman scattering in the present study. Studies in North Sea waters have shown that

Table 6. Linear relationships $(\mathrm{POC}=a \mathrm{chl} a+b)$ between POC $\left(\mathrm{mg} \mathrm{m}^{-3}\right)$ and chl a $\left(\mathrm{mg} \mathrm{m}^{-3}\right)$ in the Samnanger fjord (SAF) and the Bokna fjord (BOF). Data for the SAF are from Aure et al. (2000) and for the BOF are from the authors' unpublished results

\begin{tabular}{|c|c|c|c|c|c|}
\hline \multirow{2}{*}{$\mathrm{BOF}$} & \multirow[b]{2}{*}{ SAF } & \multicolumn{2}{|c|}{$b-$} & \multirow[b]{2}{*}{ BOF } & \multirow{2}{*}{$\mathrm{r}$} \\
\hline & & BOF & SAF & & \\
\hline 73 & 81 & 52 & 47 & $\begin{array}{c}0.79 \\
(\mathrm{n}=255)\end{array}$ & $\begin{array}{c}0.83 \\
(\mathrm{n}=288)\end{array}$ \\
\hline
\end{tabular}


below $5 \mathrm{~m}$ the errors in the estimated primary production due to contributions from Raman scattering and backscattering are negligible compared to errors caused by the variability of the level of the natural fluorescence (Morrison 2003). Compared to the ${ }^{14} \mathrm{C}$ method for measuring primary production, the method based on natural fluorescence is fast, and therefore practically applicable to large areas and long time series. Experiences have shown that the problem associated with the use of the natural fluorescence method is more significant in coastal waters where environmental conditions fluctuate more than in the open ocean (Yoshikawa \& Furuya 2004). Such a bias between coastal waters and open oceanic waters is apparent from our results (Fig. 8). It can be seen that the error by using natural fluorescence compared to ${ }^{14} \mathrm{C}$-uptake for estimation of primary production is generally higher in SAF waters (Fig. 8d) than in GNS waters (Fig. 8e). The error seems to decrease with increasing ${ }^{14} \mathrm{C}$-assimilation efficiencies (i.e. $\mathrm{g} \mathrm{C} \mathrm{g}{ }^{-1}$ chl $a \mathrm{~h}^{-1}$ ). Changing light conditions during the $24 \mathrm{~h}$ in situ incubations in the SAF compared with the constant light conditions during the $2 \mathrm{~h}$ on-deck incubations in the GNS may have contributed to the better correlation found between natural fluorescence and ${ }^{14} \mathrm{C}$-uptake in the GNS. We have validated the natural fluorescence method against the ${ }^{14} \mathrm{C}$-method for applications in fjord and oceanic waters (for coastal waters only local adaptation was possible, see 'Materials and methods'), which represent 2 extremes as far as water quality is concerned. Therefore, we expect at least the same level of accuracy when applying the natural fluorescence method to SWN waters as that achieved in our application of it to fjord water (Fig. 8a).

According to Neale et al. (1998b) the depth of the mixed-layer may be critical for the degree of UVR damage, if inhibition is considered to be a function of cumulative exposure (i.e. dose dependent). In the upper layer of the water column, vertical mixing over scales of metres $(<20 \mathrm{~m})$ is assumed to take from a few hours to a day, depending upon the magnitude of the wind stress. Fundamental in this context is the fact that physical and biological processes occur on similar scales (Denman \& Powell 1984). In a study in Bahía Engaño (Argentina) Barbieri et al. (2002) found that in order to avoid significant UVR-induced reduction of the integrated primary production, the depth of the upper mixed-layer $\left(Z_{\mathrm{UML}}\right)$ must approach the depth of the euphotic zone $\left(Z_{\mathrm{Eu}}\right)$ (i.e. $Z_{\mathrm{UML}} / Z_{\mathrm{Eu}}=0.91$ ). The mixed-layer depths in the waters of the GNS, the SWN and the SAF were 20-40, 7-15 and 1-10 m, respectively (Fig. 2). The euphotic zone extended deeper down than the $1 \%$ UVR depths at $380 \mathrm{~nm}$ (see 'Materials and methods'), which were 22-78 m in GNS waters (except at the stations close to the East Greenland coast), 7-15 $\mathrm{m}$ in SWN waters and 2-8 $\mathrm{m}$ in SAF waters. Piazena et al. (2002) concluded that UV-A radiation penetrated down to between 50 and $94 \%$ of the depth of the euphotic zone (1\% depth of PAR) in central subtropical Atlantic waters (Types OI to OII in the Jerlov system). The mixed-layer depths were in accordance with the average vertical distribution of chl a within the 3 investigated areas (Fig. 3). Applying the $Z_{\mathrm{UML}} / Z_{\mathrm{Eu}}$ relationship to the waters covered by our investigations and assuming a dose dependency of UVR inhibition, we find that the mixed-layer depths were probably too shallow to prevent UVR-induced reduction in the integrated primary production, both in the GNS and the SAF. But due to the differences in CDOM concentrations, which were moderately high in SWN waters and high in SAF waters, we expect the most extensive UVR damage to occur in GNS waters.

The potential for UVR inhibition was considerable down to $10 \mathrm{~m}$ in the GNS, down to $5 \mathrm{~m}$ in the coastal waters of the SWN and down to $3 \mathrm{~m}$ in SAF waters (Fig. 9d to f). Based on in situ incubations around local noon in July in Kvalsund, North Norway $\left(69.9^{\circ} \mathrm{N}\right)$, UVR inhibition of primary production was found down to a depth of about $10 \mathrm{~m}$ in clear, well-mixed Barents Sea waters (Helbling et al. 1996, Helbling \& Villafañe 2002). From their data it may be inferred that inhibition of primary production due to UVR (UVA + UVB) at a depth of $5 \mathrm{~m}$ in Kvalsund was about $17 \%$ (UV-A: 10\%, UV-B: $7 \%$ ).

Due to the high transparency at the oceanic stations in the GNS (Fig. 10), relatively high values of production per gram chl a (Fig. 9j) were found down to depths of about $30 \mathrm{~m}$ at some stations (e.g. Stn 630 containing water of Atlantic origin). The high potential for inhibition of photosynthesis in the upper $10 \mathrm{~m}$ of the water column in the GNS did not, on the other hand, lead to a deeper chl a maximum than in the SAF. On the contrary, the deepest chl a maximum was encountered in the SAF (Fig. 9p-r). This probably has to do with differences in hydrographical regimes, the most stratified and stable water conditions being found in the SAF. The surface PAR intensities were not considerably different at the stations in question (Fig. 9m-o). In addition, wind-induced water exchanges between the coastal waters of the SWN and the fjord waters often result in a 2-layered system with respect to water quality, phytoplankton species composition and biomass (Frette et al. 2004). Deep chlorophyll maximum layers (DCM) may also occur in such systems during spring and summer (Erga \& Heimdal 1984, Erga 1989a). As was the case in the Bokna fjord, the DCM layers typically consisted of shade-adapted cells characterised by high ratios between concentrations of chl $a$ and $\mathrm{C}$. 
In the SAF the estimated potential for inhibition of photosynthetic rates was high close to the surface (Fig. 9e). Besides this, both nitrate and orthophosphate concentrations were close to the limit of detection in the upper $10 \mathrm{~m}$ of the water column from mid-March until October (see 'Results'). This could have an effect on the vertical distribution of the phytoplankton and be a stress factor in addition to the UV irradiance in the surface layer (Lesser et al. 1994). However, due to the high concentrations of CDOM in the SAF, the estimated potential for inhibition of photosynthetic rates was very low below a depth of 2 to $3 \mathrm{~m}$ (Fig. 9e) compared with that in the GNS (Fig. 9d). It should also be noted that in the coastal waters of the SWN, the UVR potential for inhibition was generally highest on Transect II (except at Stn 6), while the lowest was found on Transect III (Fig. 9f). This is in good accordance with the mean values of CDOM concentrations in the upper $10 \mathrm{~m}$ of the water column on these transects, which were calculated to be $2.21 \mathrm{~m}^{-1}$ on Transect I, $1.94 \mathrm{~m}^{-1}$ on Transect II and $2.35 \mathrm{~m}^{-1}$ on Transect III. Such a pattern is to be expected due to correlations both between $K_{\mathrm{d}}$ (UV) and potential for inhibition (Fig. 9d-f), and between $K_{\mathrm{d}}$ (UV) and CDOM (Fig. 10).

A more theoretical approach to photosynthetic efficiencies was obtained by using PAR and UVR combined with a parameterisation of UVR-inhibited primary production (Cullen et al. 1992, Neale et al. 1998a). From such model calculations it appears that the photosynthetic efficiencies were generally lower in the GNS than in the fjord waters of the SAF and the coastal waters of the SWN (Fig. 9g-i). These results are not in accordance with the results for the production per gram chl a rates derived from natural fluorescence (Fig. 9j-1), which predicted high values more frequently in the GNS. The lower values in the GNS predicted by the model calculations could be due to the way in which the factor $P^{\mathrm{B}}{ }_{\mathrm{s}}$ was obtained (see 'Material and methods'). Thus, the apparent difference between the 2 production rates in the GNS is caused by the fact that the model in this case predicts higher production deep in the water column, while the fluorescence measurements yield higher production in the upper part of the water column. Both long-term light adaptation (i.e. light history) and short-term light acclimation of phytoplankton may have been contributing factors in the last case.

In order to compare our photosynthetic rates in the SAF with the results of Chamberlin \& Marra (1992), we did some simplifications. No corrections were made to compensate for excretion of photosynthesised products during incubations, since this depends very much upon the physiological conditions of the cells. Photorespiration was probably not a problem, since only data from depths $>5 \mathrm{~m}$ were included. Grazing activity and heterotrophic respiration could have reduced the levels of incorporated ${ }^{14} \mathrm{C}$ in our bottles during the $24 \mathrm{~h}$ incubation period. According to Harris (1986), dark respiration of natural phytoplankton seldom exceeds $10 \%$ of the photo-assimilated carbon. Discrepancies due to diurnal periodicity in photosynthesis-irradiance relationships (Harding et al. 1987, Erga \& Skjoldal 1990) may affect the natural fluorescence yields. From a total evaluation, however, we chose not to correct for these possible sources of error.

Chamberlain \& Marra (1992), who comprised data from many different oceanic and coastal localities, found values for $\left(\varphi_{\mathrm{c}} / \varphi_{\mathrm{f}}\right)_{\max }$ (carbon atoms per photon) ranging from 0.22 to 1.99 , depending on the water type. This ratio is interesting because it represents the maximum ratio of the quantum yields and hence the potential of phytoplankton in different water types to perform photosynthesis. Considering the photosynthetic parameters we have derived for the 3 different study areas (Table 1$)$, we see that $\left(\varphi_{\mathrm{c}} / \varphi_{\mathrm{f}}\right)_{\max }$ and $P_{\mathrm{s}}^{\mathrm{B}}$ ( $\mathrm{g} \mathrm{C} \mathrm{g} \mathrm{g}^{-1} \mathrm{Chl} \mathrm{a} \mathrm{h}^{-1}$ ) are highest in SWN waters. This finding is consistent with the prevailing nutrient conditions, which show that nutrient limitation of photosynthesis was less probable in these waters than in the fjord and oceanic waters of the SAF and GNS, respectively (see 'Results'). The tendency of high subsurface photosynthetic efficiencies in all investigation areas (Fig. $9 \mathrm{~g}$ to $\mathrm{l}$ ) is to be expected since $\varphi_{\mathrm{c}}$ will be less than $\varphi_{\max }$ when $E>E_{\mathrm{s}}$.

From our results it may be concluded that the optical properties of the investigated water masses are highly influenced by circulation patterns. In the GNS, chl a contributed significantly to the attenuation of UVR, but even though the CDOM concentrations are known to be low in oceanic waters, we expect that also CDOM will contribute to attenuation of the UV-B radiation in the GNS. The highest $K_{\mathrm{d}}$ values in the GNS were encountered in the current systems on the east coast of Greenland and the west coast of Bear Island. During windy periods, extensive water exchanges take place between fjord waters of the SAF and NCC waters. Such water mass exchanges lead to corresponding exchanges of both CDOM and phytoplankton biomass, which affect the optical properties of both fjord water and NCC water. In accordance with this, the CDOM concentrations were found to be the same below $10 \mathrm{~m}$ in the waters of the SWN and the SAF. However, due to high concentrations of CDOM in the upper $10 \mathrm{~m}$ layer of the SAF, CDOM was by far the most important contributor to UVR attenuation in the SAF. In NCC waters, on the other hand, the role of CDOM was less obvious, but it was still more important than chl a for UVR attenuation. The deeper penetration of UVR in GNS waters than in SWN waters did not lead to a DCM layer in the GNS. On the contrary, as judged from the 
average vertical distribution of chl $a_{\text {, a DCM layer was }}$ found at a depth of $20 \mathrm{~m}$ in SWN waters, while in the GNS the highest chl a concentrations were restricted to the upper $10 \mathrm{~m}$ of the water column, but relatively high values were found down to a depth of $30 \mathrm{~m}$. In the central part of the GNS, both nitrate and silicate could be limiting the growth of phytoplankton in the upper $20 \mathrm{~m}$ layer, while in the core of NCC waters nitrate concentrations were relatively low down to a depth of at least $10 \mathrm{~m}$. In the SAF the highest phytoplankton concentrations were most frequently encountered closer to the surface. Here, nitrate and phosphate were depleted in the upper $10 \mathrm{~m}$ of the water column during the period from April to October. These differences in nutrient conditions were probably due to differences in the mixed-layer depths, which were larger in GNS waters than in the waters off the SWN and smallest in SAF waters. The highest degree of conformity between primary production estimates obtained from measurements of natural fluorescence and ${ }^{14} \mathrm{C}$-assimilation were achieved in the oceanic waters of the GNS. We would therefore recommend that natural fluorescence measurements are validated against short $(2 \mathrm{~h}){ }^{14} \mathrm{C}$ uptake measurements several times during the day, and that the 2 measurements are conducted as simultaneously as possible. The maximum quantum yield and integrated photosynthetic efficiency of the water column were highest in SWN waters. Our data show that the maximum and mean percentage potential for inhibition of primary production due to UVR at a depth of $5 \mathrm{~m}$ were 11 and $4.3 \%$ in the GNS, 3.2 and $0.9 \%$ in the SWN and 0.5 and $0.1 \%$ in the SAF.

Acknowledgements. This work was supported by the Norwegian Research Council. We thank the crews of RV 'Hans Brattstrøm', RV 'Johan Hjort' and RV 'Håkon Mosby' for their kind assistance during the cruises. Special thanks go to Ole Magnus Gjervik and Øyvind Østensen and to Christine Daae Olseng and Sjur Gjelland for valuable help during the cruises with RV 'Hans Brattstrøm' and RV 'Håkon Mosby', respectively. We are greatly indebted to 3 anonymous reviewers for constructive input and comments on the manuscript.

\section{LITERATURE CITED}

Aas E (2000) Spectral slope of yellow substance: problems caused by small particles. In: Proc OCEAN OPTICS XV. Office of Naval Research, USA, CD-ROM

Aas E, Højerslev NK (2001) Attenuation of ultraviolet irradiance in North European waters. Oceanologia 43:139-168

Aas E, Høkedal J (1996) Penetration of ultraviolet B, blue and quanta irradiance into Svalbard waters. Polar Res 15:27-138

Arrigo KR (1994) Impact of ozone depletion on phytoplankton growth in the Southern Ocean: large-scale spatial and temporal variability. Mar Ecol Prog Ser 114:1-12

Aure J, Molvær J, Stigebrandt A (1996) Observations of inshore water exchange forced by a fluctuating offshore density field. Mar Pollut Bull 33:112-119
Aure J, Danielssen D, Svendsen E (1998) The origin of Skagerrak coastal water off Arendal in relation to variations in nutrient concentrations. ICES J Mar Sci 55: $610-619$

Aure J, Erga SR, Asplin L (2000) Increased biological production in fjords by artificial upwelling. Fisken Havet 11:1-30

Austin J, Butchart N, Shine KP (1992) Possibility of an Arctic ozone hole in a doubled- $\mathrm{CO}_{2}$ climate. Nature 360:221-225

Barbieri ES, Villfañe VE, Helbling EW (2002) Experimental assessment of UV effects on temperate marine phytoplankton when exposed to variable radiation regimes. Limnol Oceanogr 47:1648-1655

Bjørn LO, Callaghan TV, Gehrke C, Johanson M, GwynnJones D (1998) The problem of ozone depletion in northern Europe. Ambio 27:275-279

Blindheim J, Skjoldal HR (1993) Effects of climatic changes on the biomass yield of the Barents Sea, Norwegian Sea, and West Greenland large marine ecosystems. In: Sherman K, Alexander LM, Gold D (eds) Large marine ecosystems. AAAS Press, Washington, DC, p 185-198

Browman H, Rodriguez CA, Béland F, Cullen JJ and 7 others (2000) Impact of ultraviolet radiation on marine crustacean zooplankton and ichthyoplankton: a synthesis of results from the estuary and Gulf of St. Lawrence, Canada. Mar Ecol Prog Ser 199:293-311

Chamberlin S, Marra J (1992) Estimation of photosynthetic rate from measurements of natural fluorescence: analysis of the effects of light and temperature. Deep-Sea Res 39: 1695-1706

Cullen JJ, Neale PJ (1994) Ultraviolet radiation, ozone depletion, and marine photosynthesis. Photosynth Res 39:303-320

Cullen JJ, Neale PJ (1997) Effect of UV on short-term photosynthesis of natural phytoplankton. Photochem Photobiol 65:264-266

Cullen JJ, Neale PJ, Lesser MP (1992) Biological weighting function for the inhibition of phytoplankton photosynthesis by ultraviolet radiation. Science 258:646-650

Dahlback A (2002) Recent changes in surface ultraviolet solar radiation and stratospheric ozone at a high Arctic site. In: Hessen DO (ed) UV radiation and Arctic ecosystems. Ecological Studies 153, Springer-Verlag, Berlin, p 3-22

Davidson AT, van der Heijden A (2000) Exposure of natural Antarctic marine microbial assemblages to ambient UV radiation: effects on bacterioplankton. Aquat Microb Ecol 21:257-264

Denman KL, Powell TM (1984) Effects of physical processes on planktonic ecosystems in the coastal ocean. Oceanogr Mar Biol Annu Rev 22:125-168

Dring MJ, Wagner A, Franklin LA, Kuhlenkamp R, Lüning K (2001) Seasonal and diurnal variations in ultraviolet-B and ultraviolet-A irradiances at and below the sea surface at Helgoland (North Sea) over a 6-year period. Helgol Mar Res 55:3-11

Erga SR (1989a) Ecological studies on the phytoplankton of Boknafjorden, western Norway. I. The effect of water exchange processes and environmental factors on temporal and vertical variability of biomass. Sarsia 74:161-176

Erga SR (1989b) Ecological studies on the phytoplankton of Boknafjorden, western Norway. II. Environmental control of photosynthesis. J Plankton Res 11:785-812

Erga SR, Heimdal BR (1984) Ecological studies on the phytoplankton of Korsfjorden, western Norway. The dynamics of a spring bloom seen in relation to hydrographical conditions and light regime. J Plankton Res 6:67-90

Erga SR, Skjoldal HR (1990) Diel variations in photosynthetic activity of summer phytoplankton in Lindåspollene, western Norway. Mar Ecol Prog Ser 65:73-85 
Frette $\varnothing$, Erga SR, Hamre B, Aure J, Stamnes JJ (2004) Seasonal variability in inherent optical properties in a western Norwegian fjord. Sarsia 89:276-291

Garcia-Mendoza E, Maske H (1996) The relationship of solarstimulated natural fluorescence and primary productivity in Mexican Pacific waters. Limnol Oceanogr 41: $1697-1710$

Gibson JAE, Vincent WF, Nieke B, Pienitz R (2000) Control of biological exposure to UV radiation in the Arctic Ocean: comparison of the roles of ozone and riverine dissolved organic matter. Arctic 53:372-382

Gjerstad KI, Stamnes JJ, Hamre B, Lotsberg JK, Yan B, Stamnes K (2003) Monte Carlo and discrete-ordinate simulations of irradiances in the coupled atmosphereocean system. Appl Opt 42:2609-2622

Green SA, Blough NV (1994) Optical absorption and fluorescence properties of chromophoric dissolved organic matter in natural waters. Limnol Oceanogr 39:1903-1916

Häder D-P, Worrest RC, Kumar HD, Smith RC (1995) Effects of increased solar ultraviolet radiation on aquatic ecosystems. Ambio 24:174-180

Hamre B, Frette Ø, Erga SR, Stamnes JJ (2003) Parameterization and analysis of the optical absorption and scattering coefficients in a western Norwegian fjord-A case II water study. Appl Opt 42:883-892

Hamre B, Winther JG, Gerland S, Stamnes JJ, Stamnes K (2004) Modeled and measured transmittance of snow covered first year sea ice in Kongsfjorden, Svalbard. J Geophys Res 109: C10006. DOI:10.1029/2003JC001926

Harding LW Jr, Tyler MA, Fisher TR Jr (1987) Adaptive responses of photosynthesis in phytoplankton: specificity to time scale of change in light. Biol Oceanogr 4:403-437

Harris GP (ed) (1986) Phytoplankton ecology. Chapman and Hall, London

Helbling EW, Villafañe VE (2002) UV radiation effects on phytoplankton primary production: a comparison between Arctic and Antarctic marine ecosystems. In: Hessen DO (ed) UV radiation and Arctic ecosystems. Ecological Studies 153, Springer-Verlag, Berlin, p 203-226

Helbling EW, Eilertsen HC, Villafañe VE, Holm-Hansen O (1996) Effects of UV radiation on post-bloom phytoplankton populations in Kvalsund, North Norway. J Photochem Photobiol B Biol 33:255-259

Hessen DO (ed) (2002) UV radiation and Arctic ecosystems. Ecological Studies 153, Springer-Verlag, Berlin

Hofmann DJ, Oltmans SJ, Harris JM, Solomon S, Deshler T, Johnson BJ (1992) Observation and possible causes of new ozone depletion in Antarctica in 1991. Nature 359: 283-287

Holm-Hansen O, Lorenzen CJ, Holmes RW, Strickland JDH (1965) Fluorometric determination of chlorophyll. J Cons Int Explor Mer 30:3-15

Holm-Hansen O, Helbling EW, Lubin D (1993a) Ultraviolet radiation in Antarctica: inhibition of primary production. Photochem Photobiol 58:567-570

Holm-Hansen O, Lubin D, Helbling EW (1993b) Ultraviolet radiation and its effects on organisms in aquatic environments. In: Young AR, Bjørn LO, Moan J, Nultsch W (eds) Environmental UV photobiology. Plenum Press, New York, p 379-425

Højerslev NK, Aas E (1991) A relationship for the penetration of ultraviolet B radiation into the Norwegian Sea. J Geophys Res 96:17003-17005

Højerslev NK, Aas E (1998) Spectral light absorption by gelbstoff in coastal waters displaying highly different concentrations. In: Proc OCEAN OPTICS XIV. Office of Naval Research, Honolulu, CD-ROM
Højerslev NK, Aas E (2001) Spectral light absorption by yellow substance in the Kattegat-Skagerrak area. Oceanologia 43:39-60

Jerlov NG (1976) Marine optics. Elsevier Oceanogr Ser 14: $1-231$

Jin Z, Stamnes K (1994) Radiative transfer in nonuniformly refracting layered media: atmosphere-ocean system. Appl Opt 33:431-442

Jokela K, Leszczynski K, Visuri R (1993) Effects of Arctic ozone depletion and snow on UV exposure in Finland. Photochem Photobiol 58:559-566

Keller AA, Hargraves P, Jeon H, Klein-MacPhee G, Klos E, Oviatt C, Zhang J (1997) Effects of ultraviolet-B enhancement on marine trophic levels in a stratified coastal system. Mar Biol 130:277-287

Kjeldstad B, Frette Ø, Erga SR, Browman HI, Kuhn P, Davis R, Miller W, Stamnes JJ (2003) UV (280 to $400 \mathrm{~nm}$ ) optical properties in a Norwegian fjord system and an intercomparison of underwater radiometers. Mar Ecol Prog Ser 256: $1-11$

Kuwahara VS, Ogawa H, Toda T, Kikuchi T, Taguchi S (2000) Variability of bio-optical factors influencing the seasonal attenuation of ultraviolet radiation in temperate coastal waters of Japan. Photochem Photobiol 72:193-199

Laurion I, Lean DRS, Vincent WF (1998) UVB effects on a plankton community: results from a large-scale enclosure assay. Aquat Microb Ecol 16:189-198

Lesser MP, Cullen JJ, Neale PJ (1994) Carbon uptake in a marine diatom during acute exposure to ultraviolet $\mathrm{B}$ radiation: relative importance of damage and repair. J Phycol 30:183-192

Maritorena S, Morel A, Gentili B (2000) Determination of the fluorescence quantum yield by oceanic phytoplankton in their natural habitat. Appl Opt 39:6725-6737

Mobley CD, Gentili B, Gordon HR, Jin Z and 5 others (1993) Comparison of numerical models for computing underwater light fields. Appl Opt 32:215-218

Morel A, Maritorena S (2001) Bio-optical properties of oceanic waters: a reappraisal. J Geophys Res 106: 7163-7180

Morrison JR (2003) In situ determination of the quantum yield of phytoplankton chlorophyll a fluorescence: a simple algorithm, observations, and a model. Limnol Oceanogr 48:618-631

Neale PJ, Cullen JJ, Davis RF (1998a) Inhibition of marine photosynthesis by ultraviolet radiation: variable sensitivity of phytoplankton in the Weddell-Scotia Confluence during the austral spring. Limnol Oceanogr 43:433-448

Neale PJ, Davis RF, Cullen JJ (1998b) Interactive effects of ozone depletion and vertical mixing on photosynthesis of Antarctic phytoplankton. Nature 392:585-589

Nielsen TG, Løkkegaard B, Richardson K, Pedersen FB, Hansen L (1993) Structure of plankton communities in the Dogger Bank area (North Sea) during a stratified situation. Mar Ecol Prog Ser 95:115-131

Obernosterer I, Benner R (2004) Competition between biological and photochemical processes in the mineralization of dissolved organic carbon. Limnol Oceanogr 49:117-124

Olsen A, Johannessen T, Rey F (2003) On the nature of the factors that control spring bloom development at the entrance to the Barents Sea and their interannual variability. Sarsia 88:379-393

Parsons TR, Maita Y, Lalli CM (1992) A manual of chemical and biological methods for sea water analysis. Pergamon Press, New York

Piazena H, Perez-Rodrigues E, Häder D-P, Lopez-Figueroa F (2002) Penetration of solar radiation into the water column 
of the central subtropical Atlantic Ocean-optical properties and possible biological consequences. Deep-Sea Res II 49:3513-3528

Platt T, Gallegos CL, Harrison WG (1980) Photoinhibition of photosynthesis in natural assemblages of marine phytoplankton. J Mar Res 38:687-701

Rey F, Noji TT, Miller LA (2000) Seasonal phytoplankton development and new production in the central Greenland Sea. Sarsia 85:329-344

Roy S (2000) Strategies for the minimisation of UV-induced damage. In: DeMora S, Demers S, Vernet M (eds) The effects of UV radiation in the marine environment. Cambridge environmental chemistry series, Cambridge University Press, Cambridge, p 177-205

Smith RC, Prezelin BB, Baker KS, Bidigare RR and 9 others (1992) Ozone depletion: ultraviolet radiation and phytoplankton biology in Antarctic waters. Science 255: 952-959

Stamnes K, Tsay SC, Wiscombe W, Jayaweera K (1988) Numerically stable algorithm for discrete-ordinatemethod radiative transfer in multiple scattering and emitting layered media. Appl Opt 27:2502-2509

Steemann Nielsen E (1952) The use of radio-active carbon $\left({ }^{14} \mathrm{C}\right)$ for measuring organic production in the sea. J Cons Perm Int Explor Mer 18:117-140

Stolarski R, Bojkov R, Bishop L, Zerefos C, Staehelin J, Zawodny J (1992) Measured trends in stratospheric ozone. Science 256:342-349

Sætre R, Aure J, Ljøen R (1988) Wind effects on the lateral extension of the Norwegian coastal water. Cont Shelf Res 8:239-253

Tsay SC, Stamnes K (1992) Ultraviolet radiation in the Arctic:

Editorial responsibility: Howard I. Browman (Associate Editorin-Chief), Storebø, Norway the impact of potential ozone depletion and cloud effects. J Geophys Res 97:7829-7840

Utermöhl H (1931) Neue Wege in der quantitativen Erfassung des Planktons. (Mit besonderer Berücksichtigung des Ultraplanktons). Verh Int Verein Theor Angew Limnol 5: 567-596

Varotsos CA, Chronopoulos GJ, Cracknell AP, Johnson BE, Katsambas A, Philippou A (1998) Total ozone and solar ultraviolet radiation, as derived from satellite and groundbased instrumentation at Dundee, Scotland. Int J Remote Sens 19:3301-3305

Vasseur C, Mostajir B, Nozais C, Denis M, Fouilland E, Klein B, Demers S (2003) Effects of bio-optical factors on the attenuation of ultraviolet and photosynthetically available radiation in the North Water Polynya, northern Baffin Bay: ecological implications. Mar Ecol Prog Ser 252:1-13

Vernet M (2000) Effects of UV radiation on the physiology and ecology of marine phytoplankton. In: DeMora S, Demers $S$, Vernet $M$ (eds) The effects of UV radiation in the marine environment. Cambridge environmental chemistry series, Cambridge University Press, Cambridge, p 237-278

Westberry TK, Siegel DA (2003) Phytoplankton natural fluorescence variability in the Sargasso Sea. Deep-Sea Res I 50:417-434

Yoshikawa T, Furuya K (2004) Long-term monitoring of primary production in coastal waters by an improved natural fluorescence method. Mar Ecol Prog Ser 273:17-30

Zagarese HE, Williamson CE (2000) Impact of solar UV radiation on zooplankton and fish. In: DeMora S, Demers $\mathrm{S}$, Vernet M (eds) The effects of UV radiation in the marine environment. Cambridge environmental chemistry series, Cambridge University Press, Cambridge, p 279-309

Submitted: January 27, 2005; Accepted: June 17, 2005 Proofs received from author(s): November 10, 2005 